\title{
33. PALEOLATITUDES AND TECTONIC RECONSTRUCTIONS OF THE OLDEST PORTION OF THE PACIFIC PLATE: A COMPARATIVE STUDY ${ }^{1}$
}

\author{
R. L. Larson, ${ }^{2}$ M. B. Steiner, ${ }^{3}$ E. Erba, ${ }^{4}$ and Y. Lancelot ${ }^{5}$
}

\begin{abstract}
Studies of remanent magnetic inclinations and paleoecology of planktonic communities in sediments recovered during Ocean Drilling Program Leg 129 are combined with the skewness of M-sequence magnetic anomalies, paleomagnetism of seamounts, and Pacific plate motion models based on fixed hotspots to derive the paleolatitude and plate tectonic histories of the oldest portion of the Pacific plate. It originated as a small plate, perhaps of microplate dimensions, at equatorial southern paleolatitudes during the Middle Jurassic. The Pacific plate drifted south from the Kimmeridgian throughout the remaining Late Jurassic and Early Cretaceous, carrying Site 801 to a maximum southern paleolatitude of $22^{\circ} \mathrm{S}$, which is $40^{\circ}$ south of its present-day location. This southward drift was accompanied by about $30^{\circ}$ of clockwise rotation. The southward motion tapered off, and was replaced by northward drift sometime between the Hauterivian and the Aptian, perhaps near the Aptian/Barremian boundary. This was probably in response to changing mantle dynamics associated with the mid-Cretaceous superplume episode. The Pacific plate drifted northward throughout the Late Cretaceous, and Site 801 crossed the paleoequator from south to north during the late Campanian (75-80 Ma). Northward motion continued until the late Eocene $(43 \mathrm{Ma}$ ) when true polar wander, possibly induced by the collision of India and Africa/Arabia against Eurasia, caused $8^{\circ}$ of retrograde (southern) motion of the Pacific plate relative to the spin axis and paleoequator. The Pacific plate has drifted monotonically to the northwest since the Eocene, and that motion continues today.
\end{abstract}

\section{INTRODUCTION}

Paleolatitude studies were conducted in conjunction with Leg 129 by three independent techniques: remanent magnetic inclination of the cored sediments (Steiner and Wallick, this volume), paleoecology of planktonic communities (Erba, this volume), and skewness of M-sequence magnetic anomalies (Larson and Sager, this volume). Previous results from the paleomagnetism of seamounts (Sager and Pringle, 1988) and Pacific plate motion models based on fixed hotspots (Lancelot and Larson, 1975; Duncan and Hargraves, 1984) will be compared with these new results. As recognized by Gordon (1990), this multifaceted approach is probably the most powerful technique possible for deducing the paleolatitude history of oceanic plates. It depends on the integration of independent data sets based on independent assumptions (e.g., hotspot motion models, an axially geocentric dipole, and an equatorially centered high-primary productivity zone). An intercomparison of these independent analyses can point out the consistencies or inconsistencies among the various data sets and/or models, lending support to the consistent data sets and models and casting suspicion on the inconsistent ones.

The point of general interest that links all these studies is the assumption that the Leg 129 sites (Fig. 1) have been part of the Pacific plate for all, or at least the majority, of their geological history. If this assumption is true, then results from the Leg 129 core material can be used to constrain the history of Pacific plate motion. It is almost certain that this is valid for Site 800 because it lies on magnetic lineations that can be associated with the Pacific flank of the PacificIzanagi plate boundary (Handschumacher et al., 1988; Nakanishi et

\footnotetext{
'Larson, R. L., Lancelot, Y., et al., 1992. Proc. ODP, Sci. Results, 129; College Station, TX (Ocean Drilling Program).

${ }^{2}$ Graduate School of Oceanography, University of Rhode Island, Narragansett, RI, 02882, U.S.A.

${ }^{3}$ Department of Geology and Geophysics, University of Wyoming, Laramie, WY 82701, U.S.A.

${ }_{4}^{4}$ Dipartimento di Scienze della Terra, Via Mangiagalli 34, I-20133 Milano, Italy.

${ }^{5}$ Laboratoire de Geologie du Quaternaire, CNRS-Luminy, Case 907, 13288 Marseille, Cedex 9, France.
}

al., in press). Although Site 801 lies in a magnetic quiet zone, and Site 802 is close to poorly identified magnetic lineations, they are surrounded on the north, south, and east sides by magnetic lineations that presumably formed at various Pacific plate boundaries. This is a strong indication that these sites are also of Pacific plate origin. Although the assumption that the Phoenix lineations to the south are of Pacific plate origin has been questioned (Larson and Sager, this volume), it is unlikely that the alternate solution of an intervening microplate would have affected the Site 801 and 802 locations.

Proceeding on the assumption of a Pacific plate origin for all the Leg 129 sites, we shall address three things of particular interest. First, the Leg 129 studies provide the first detailed history of paleolatitude motion for the Middle Jurassic to the Early Cretaceous. Second, the equatorial crossing of the Pacific plate was recorded by the Upper Cretaceous-lower Cenozoic sediments at the Leg 129 sites. Interpretation of this equatorial crossing will strongly constrain Late Cretaceous-Cenozoic motion models for the Pacific plate because fixed-hotspot rotation poles all lie at great distances from the western Pacific. Thus, the Leg 129 data are sensitive to small errors in these models. Finally, we shall speculate on the timing of true polar wander during the Cenozoic that might have affected Pacific plate motion relative to the Earth's spin axis and paleoequator.

Very little was known of the pre-middle Cretaceous paleolatitude history of the Pacific plate before Leg 129 because almost no samples of this older material had been recovered. Uyeda and Richards (1966), Francheteau et al. (1970), and Harrison et al. (1975) modeled magnetic anomalies over Cretaceous-aged seamounts in the western Pacific to conclude that about $30^{\circ}$ of northward plate motion had taken place since those seamounts formed. Larson and Chase (1972) calculated a paleomagnetic pole location by forward modeling the skewness of magnetic anomalies M1 to M10 ( 120-130 Ma) that suggested the Pacific plate lay in the Southern Hemisphere at that time and has subsequently moved about $40^{\circ}$ north to its present location. Cande and Kent (1985) produced essentially the same result with magnetic anomalies M0 to M4 by phase shifting the anomalies to symmetry. Gordon (1990) utilized magnetic anomaly skewness, remanent inclination of basalt from Deep Sea Drilling Project (DSDP) holes, and paleomagnetic poles from two seamounts to calculate a "125 Ma" pole 


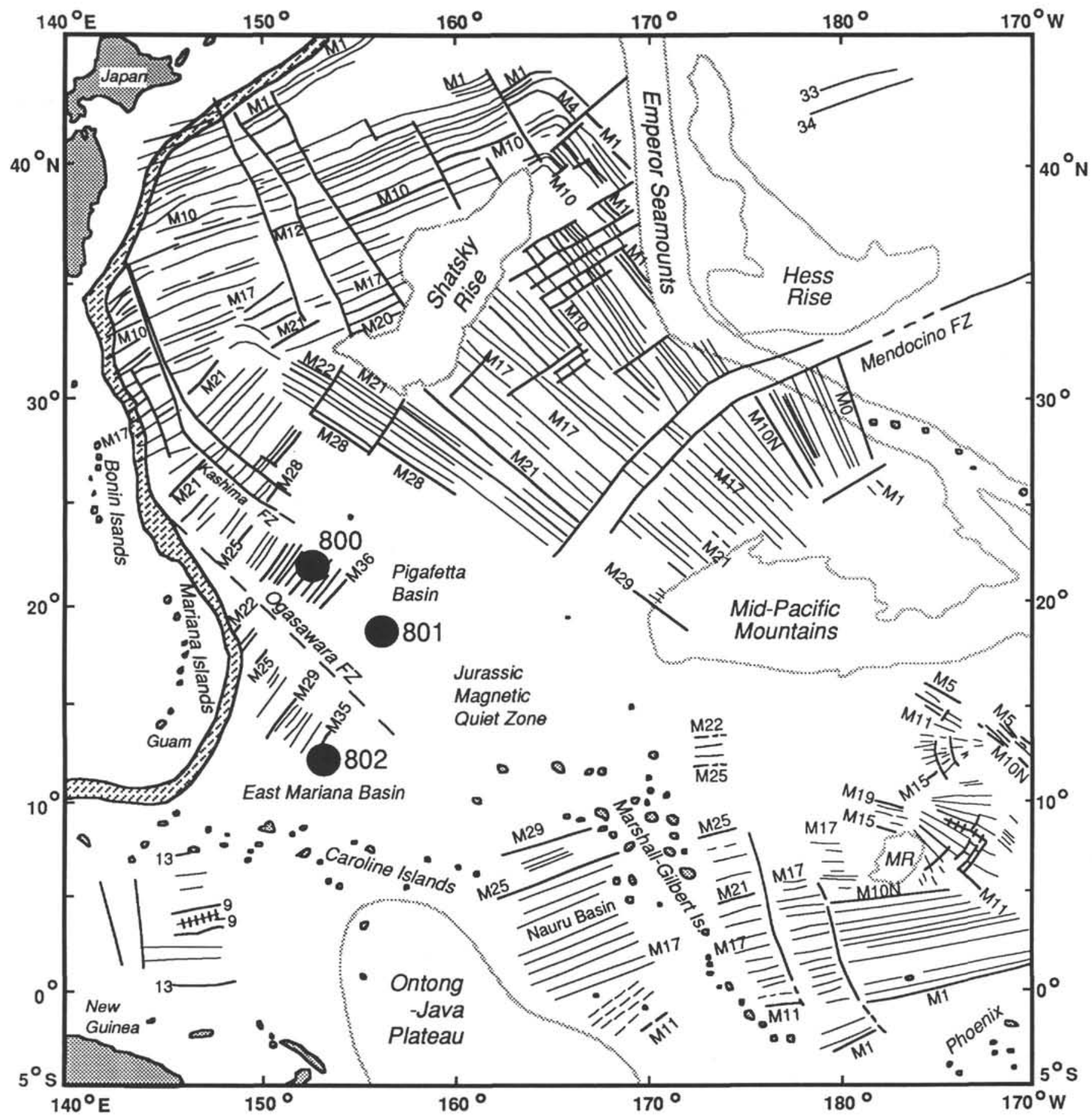

Figure 1. Large dots indicate the Leg 129 site locations (800, 801, and 802), shown with magnetic lineations of the western Pacific compiled from Hilde et al. (1976), Larson (1976), Handschumacher et al. (1988), Mammerickx and Sharman (1988), Tamaki and Larson (1988), and Nakanishi et al. (1989). MR = Magellan Rise; $\mathrm{FZ}=$ fracture zone.

located $400-500 \mathrm{~km}$ west of the original result of Larson and Chase (1972). Larson and Lowrie (1975) analyzed magnetic anomaly skewness and remanent magnetic inclinations of basalts from DSDP Site 307 on magnetic anomaly M21 ( $150 \mathrm{Ma}$ ) and concluded that only $20^{\circ}-25^{\circ}$ of net northward motion of the Pacific plate had occurred since $150 \mathrm{Ma}$. They suggested an initial southward component of Pacific plate motion and a reversal of its direction sometime during the Cretaceous as part of a general clockwise rotation of the Pacific plate. These general suggestions are all confirmed and outlined in much greater detail by the Leg
129 results, although the timing and absolute amounts of southward and northward plate motion have been revised.

\section{MIDDLE JURASSIC-EARLY CRETACEOUS PALEOLATITUDES AND RECONSTRUCTIONS}

\section{Paleolatitudes}

Figures 2-4 show paleolatitudes of the Leg 129 sites interpreted from the remanent magnetic inclinations of recovered sediment sam- 

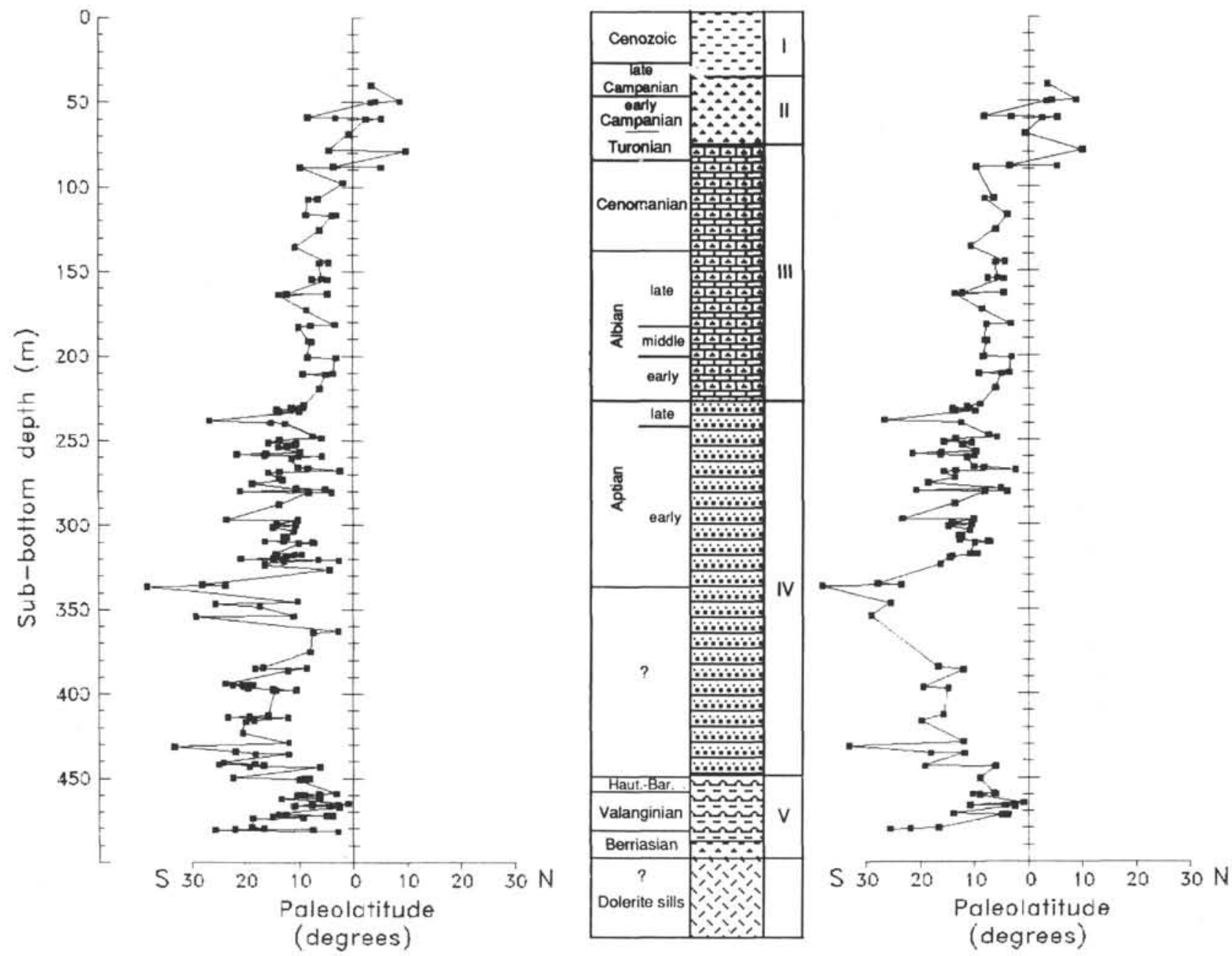

Figure 2. Site 800. Stratigraphic plot of paleolatitudes (from Steiner and Wallick, this volume). Left: Paleolatitudes from each sample in the categories judged most reliable and slightly less reliable (see Steiner and Wallick, this volume, for discussion). Right: most reliable samples only. Paleolatitudes in degrees north $(\mathrm{N})$ and south $(\mathrm{S})$ of the equator $(0)$.

ples (Steiner and Wallick, this volume). The remanent magnetizations have relatively strong intensities and relatively small secondary components. The secondary magnetizations are easily removed by both alternating field and thermal demagnetization techniques. Unblocking temperatures and coercivities suggest that the characteristic magnetization is carried by a mineral in the titanomagnetite series. The resulting inclinations are very consistent from samples within the same time periods and provide a reasonably continuous paleolatitudinal history of the oldest portion of the Pacific plate from the latest Bathonian (Middle Jurassic) to the Campanian (Late Cretaceous).

The inclinations of the Aptian through Santonian sediments of all three holes are negative. The upward directed inclinations of these sediments whose age corresponds to the Cretaceous Normal Polarity Superchron, coupled with demagnetization behaviors which indicate normal polarity, leave no doubt that this magnetization was acquired in the Southern Hemisphere. Early Cretaceous (pre-Aptian) and Jurassic sediments display normal and reversed polarity, as evinced by two different demagnetization responses. The first type of sample response displayed only decay to the origin of orthogonal axes plots with little change of declination and only steady decay of remanent intensity. The second type displayed large changes in declination (up to $180^{\circ}$ ) during demagnetization and an increase, followed by a decrease, in remanent intensity as demagnetization progressed. The first group of samples, which also includes all samples from the
Cretaceous Normal Polarity Superchron, has negative inclinations, while the second group displays positive inclinations after the completion of demagnetization. These characteristics clearly indicate that the first group of samples are normally magnetized, while the second group are reversed (Steiner and Wallick, this volume).

This demagnetization behavior, consistently observed at all sites, unambiguously indicates that the sediments from these three sites were magnetized in the Southern Hemisphere, and thus that portion of the embryonic Pacific plate resided in the Southern Hemisphere from Middle Jurassic through Late Cretaceous time. The data from Site 801 suggest that the site formed moderately close to the paleoequator in the Southern Hemisphere. The data from Sites 800 and 801 imply slow movement away from the paleoequator to succeedingly higher southern latitudes between the Kimmeridgian and Valanginian. Larger paleolatitude values recorded by Aptian sediments indicate continued southern movement during the Hauterivian-Barremian, although Site 800 contains only a very short record of this intervening interval, while a complete hiatus exists at Site 801. In the early Aptian plate motion reversed and began a northward migration. Relatively continuous northward motion, at a fairly uniform rate characterized the middle and Late Cretaceous.

Figure 5 shows the paleolatitudes of the Leg 129 sites interpreted from the skewness of M-sequence magnetic anomalies (Larson and Sager, this volume) and seamount magnetic anomalies (Sager and 

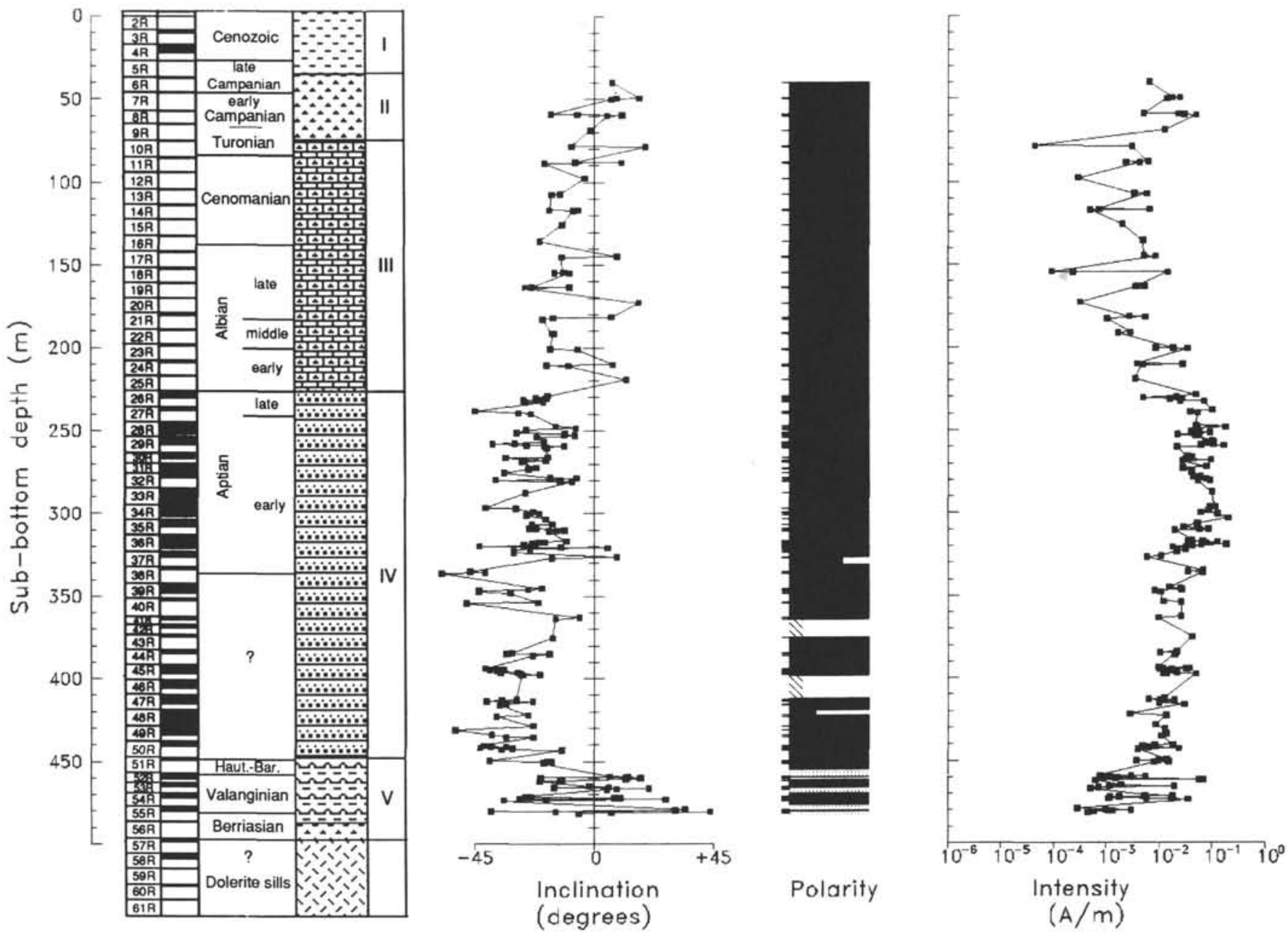

Figure 3. Site 801. Stratigraphic plot of paleolatitudes (from Steiner and Wallick, this volume). Left: Paleolatitudes from each sample in the categories judged most reliable and slightly less reliable (see Steiner and Wallick, this volume, for discussion). Right: most reliable samples only. Paleolatitudes in degrees north $(\mathrm{N})$ and south $(\mathrm{S})$ of the equator $(0)$.

Pringle, 1988). Two solutions, labeled "no anomalous skewness" and "anomalous skewness," account for a discrepancy in the skewness data that occurs mainly before M10 ( 130 Ma). Confidence lunes for the Phoenix lineations do not intersect lunes for the Hawaiian and Japanese lineations for these older anomalies, suggesting either that anomalous skewness is a significant factor, or that another plate (called the "Stealth" plate by Larson and Sager) is involved in the solution labeled "no anomalous skewness" on Figure 5. This discrepancy does not significantly affect the paleolatitude histories of any of the Leg 129 sites. The "no anomalous skewness" solution for $122 \mathrm{Ma}$ (anomalies M0 to M4) is essentially a confirmation of the same pole location calculated by Cande and Kent (1985) and Gordon (1990) for these anomalies with the same technique used by Larson and Sager (this volume).

These paleolatitude plots, like those from the remanent sediment inclinations, show that the portion of the Pacific plate containing the Leg 129 sites was in the Southern Hemisphere from the Kimmeridgian (Late Jurassic) to approximately the end of the Cretaceous. They show a pattern of southern movement from very low $\left(5^{\circ}-10^{\circ} \mathrm{S}\right)$ southern paleolatitudes in the Late Jurassic to a maximum south paleolatitude during the Barremian-Hauterivian. No skewness data are available for the Cretaceous Normal Polarity Superchron from the Aptian through the Santonian, but northward Pacific plate motion is clearly recorded in the sediment inclinations of the Aptian interval.
Paleontological data only partially reflect this plate motion during the Late Jurassic and Early Cretaceous. The position of Site 801 close to the paleoequator during the Late Jurassic is possibly reflected by nannofossil assemblage composition. While nannofossils are scarce, they suggest high-fertility conditions. In fact, both Biscutum constans and Zygodiscus erectus are relatively abundant (Erba and Covington, this volume) and possibly indicate the paleo-upwelling belt. The motion southward through the Late Jurassic and Early Cretaceous should be reflected by nannofossil and radiolarian distribution and by the sedimentary regime as well, but it is not. We would expect increases in calcareous nannofloras accompanied by a decrease in siliceous plankton, and calcareous sediments should become progressively more important. However, most of the Lower Cretaceous sequences at Sites 800 and 801 consist of radiolarite and claystone that yield abundant radiolarians and are barren of calcareous nannofossils. This is not a reflection of the general evolutionary trends of nannofossils, because these forms became numerous and a major carbonate producer in the latest Jurassic (Roth, 1986, 1989). This evolutionary pattern continued through the Early Cretaceous. The biogenic composition of pre-Aptian sediments is most probably controlled by paleoceanographic conditions favorable to preservation of siliceous organisms over calcareous forms, and not by the paleolatitude history. Dissolution of carbonates deposited beneath the $3000-4000-m$ deep carbonate compensation depth (CCD) 


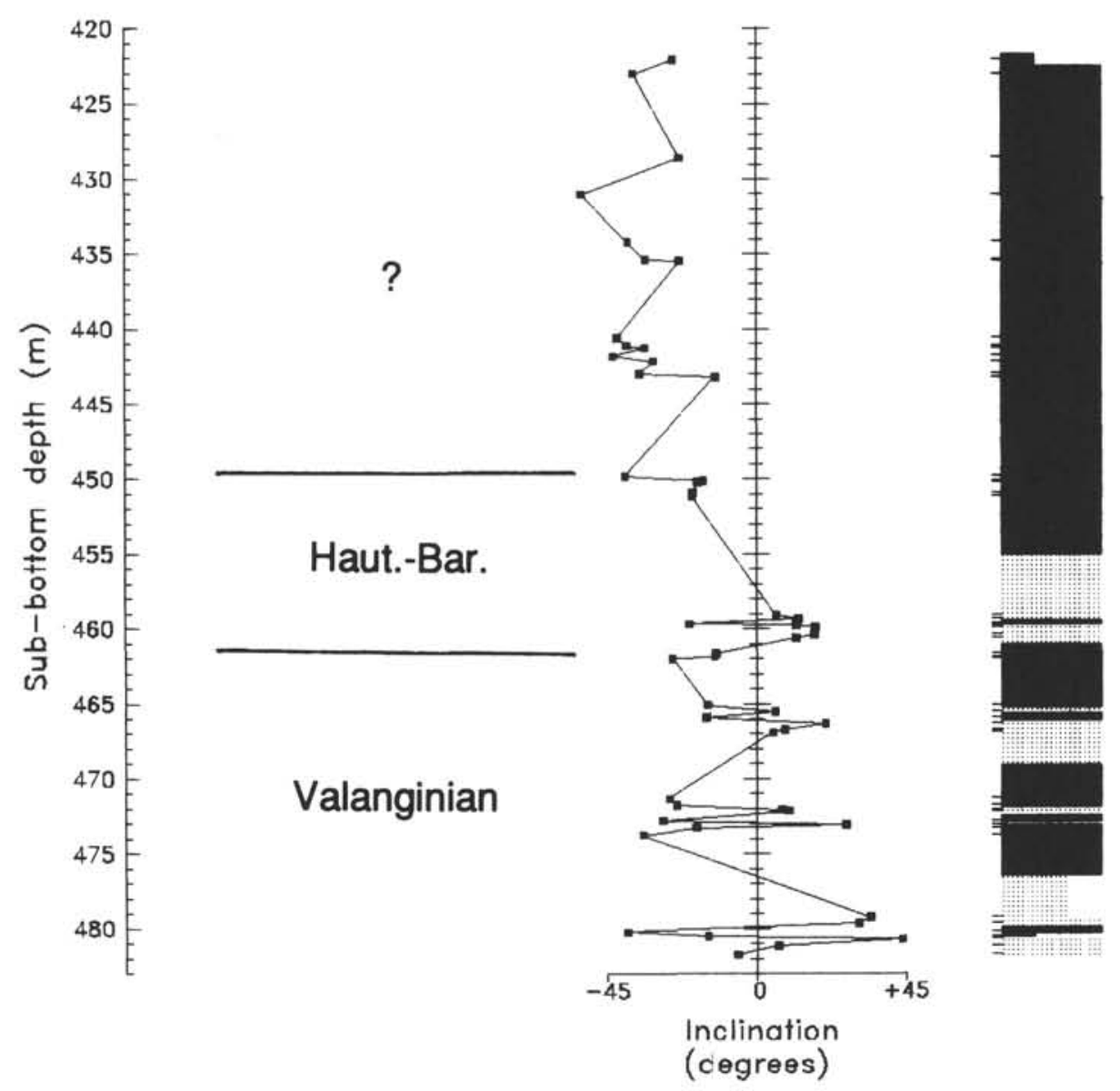

Figure 4. Site 802. Stratigraphic plot of paleolatitudes (from Steiner and Wallick, this volume). Left: Paleolatitudes from each sample in the categories judged most reliable and slightly less reliable (see Steiner and Wallick, this volume, for discussion). Right: most reliable samples only. Paleolatitudes in degrees north $(\mathrm{N})$ and south $(\mathrm{S})$ of the equator $(0)$.

(Thierstein,1979; Arthur et al., 1985) is probably the major factor determining the silica/carbonate ratio in sediment composition rather than type, rate, and magnitude of plankton productivity.

Surprisingly, biogenic pelagic carbonates became common in the mid-Cretaceous at both Sites 800 and 801 . The Aptian-Cenomanian interval is characterized by volcaniclastic turbidites with evidence of carbonates redeposited from shallow-water sites. However, several background pelagic layers occur between the redeposited events: they are mainly radiolarian-rich beds (chert, radiolarite, porcellanite, and dominantly radiolarian limestone, limestone, and chalk in the late Aptian-Albian-Cenomanian). Carbonates are relatively more abundant at Site 800 where the Albian consists entirely of limestone and chert overlying radiolarian limestone of late Aptian age. This pattern is in contrast with the history of the carbonate dissolution of the mid-Cretaceous oceans that shows a worldwide rise of the CCD in the Aptian to Santonian interval. In particular, a shallowing of some $1000 \mathrm{~m}$ was estimated in the Pacific (Thierstein, 1979; Arthur et al., 1985), that closely coincides with abnormal volcanic activity (Schlanger et al., 1981; Larson, 1991). Such extensive mid-plate volcanism probably increased the levels of dissolved $\mathrm{CO}_{2}$ in the oceans and atmosphere that controlled the accumulation/dissolution of carbonates (Arthur et al., 1985).

We cannot exclude the possibility that the mid-Cretaceous nannofossil limestone and chalk at Sites 800 and 801 are redeposited from shallower sites and thus preserved because of rapid accumulation as turbidites. However, this is unlikely because these pelagic carbonates show no evidence of reworking and do not contain shallow-water particles. In addition, there are no turbidites in the Albian-Cenomanian of Site 800 , and the planktonic calcareous and siliceous assemblages of the nonturbiditic beds preserve a clear paleoecologic signal related to the transit of the sites across the paleoequatorial upwelling area during different times. Finally, the accumulation rate of the mid-Cretaceous limestone and chert suggest pelagic sedimentation. If a pelagic depositional interpretation is correct, then the shift from exclusively siliceous biogenic sediments to a dominantly calcareous sedimentation is out of phase with the general CCD fluctuation and requires an explanation other than increased preservation of carbonates. We speculate that the lithospheric swell produced by the ascending superplume material that fed the massive mid-Cretaceous volcanic eruptions (Larson, 1991) elevated the seafloor above the CCD by Aptian time. Once Sites 800 and 801 reached paleodepths shallower than the $\mathrm{CCD}$, the blooms of the high-fertility indicators during the paleoequatorial transit could be preserved.

In general, the magnetic anomaly skewness and seamount data show higher southern paleolatitudes than do the sediment inclinations. This is probably due to "inclination flattening" resulting from sediment compaction, as suggested by Blow and Hamilton (1978), Hall and Kodama (1983), Arason and Levi (1986), Anson and Kodama (1987), and Celaya and Clement (1988). Recently, Tarduno (1990) and Gordon (1990) have demonstrated generally 

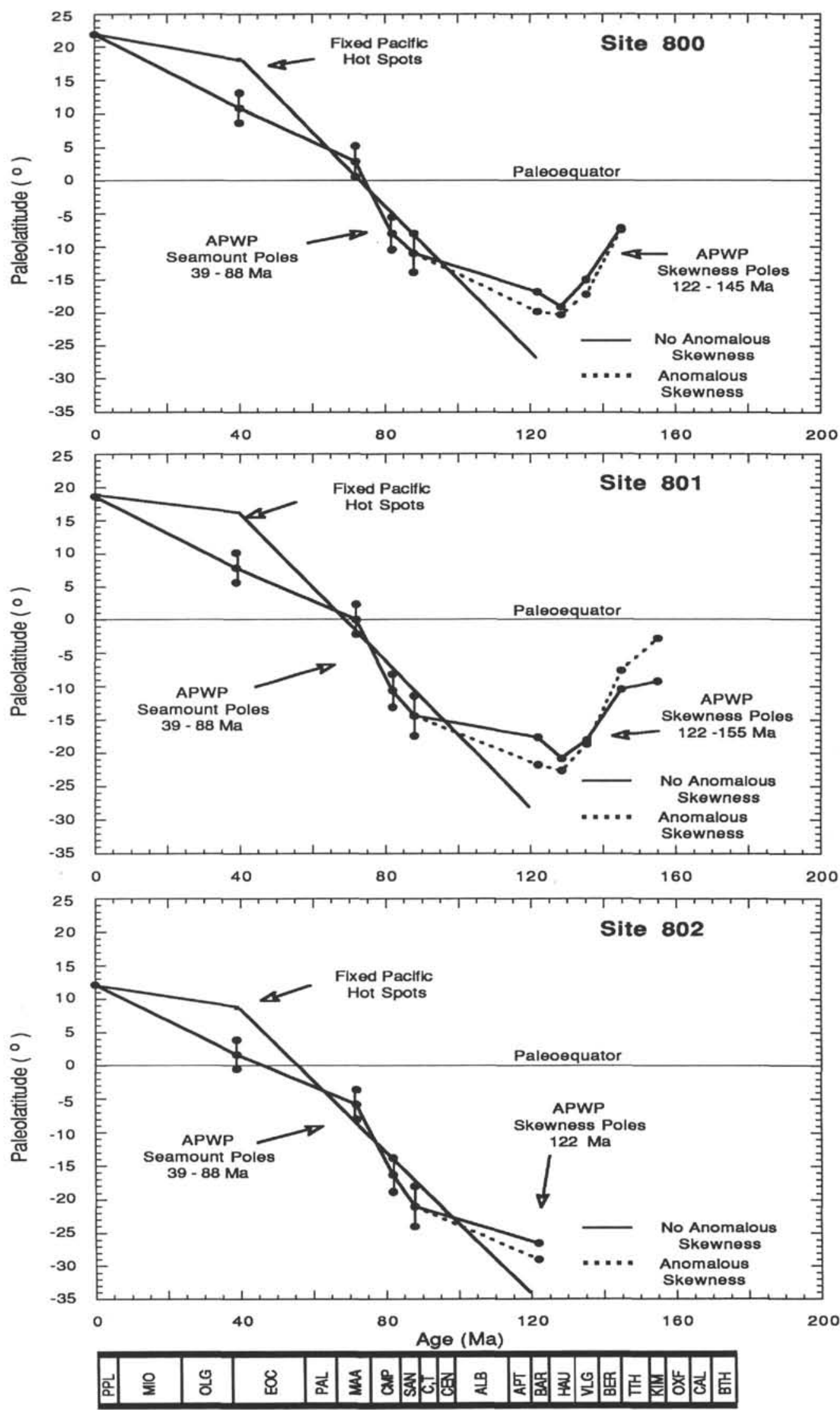

Figure 5. Predicted paleolatitudes for Leg 129 drill site locations calculated from the APWP in Figure 5 for 0-155 Ma and from the fixed hotspot model of Lancelot and Larson (1975) for 0-125 Ma. Error bars from the seamount poles (39-88 Ma) correspond to the limits of the $95 \%$ confidence ellipses. Similar-sized errors are associated with the magnetic lineation poles (122-155 Ma) but are not shown for clarity. Geological time scale calibration is from Kent and Gradstein (1985). 
shallower sediment vs. basalt-derived inclinations of the same age in the western Pacific, as well as in other parts of the Pacific (Tarduno, 1990).

Alternatively, Ogg et al. (this volume) argue that the sediment inclinations are likely to give the correct paleolatitude because those results match basalt inclinations at Sites 462 and 802 . However, the basalts recovered at Site 802 are of insufficient time duration to have averaged geomagnetic secular variation. Reliable paleolatitudes can only be derived from basalt inclinations when the igneous sequence sampled spans a time period sufficiently long to average secular variation. Single-bit holes rarely penetrate sufficient numbers of igneous units to achieve this, and Site 802 was no exception. Singlebit basalt inclinations have been used to estimate paleolatitude by the technique of averaging several site means of approximately the same age. Such an average is somewhat more likely to have canceled the effects of secular variation. When comparisons have been made among seamount poles, magnetic anomaly skewness, and basalt inclinations averaged in the above manner, the match is usually good, while sediment inclinations are usually shallower (Tarduno, 1990; Gordon, 1990). Finally, even for re-entry at Site 462 it was suspected that the inclination results were significantly influenced by secular variation (Steiner, 1981; Shipboard Scientific Party, 1986).

The oldest (Callovian) sediment inclinations from Site 801 indicate a paleolatitude of $6^{\circ} \pm 3^{\circ} \mathrm{S}$ (Steiner and Wallick, this volume). This value agrees with the $9^{\circ} \pm 2^{\circ} \mathrm{S}$ value calculated from the underlying tholeiitic basalts (Wallick and Steiner, this volume) when correction is made for the $\sim 20^{\circ}$ of tilt observed in the bedding of the Callovian sediments. However, application of this correction to the tholeiites may be inappropriate because these sediments rest on an off-axis volcanic pile of alkalic basalts, which in turn overlie the tholeiites. In other words, this tilt may not be related to the tholeiites, but rather to the subsequently emplaced alkalic basalts. The uncorrected paleolatitude derived from the tholeiites is $18^{\circ} \pm 2^{\circ} \mathrm{S}$. Magnetic anomaly skewness predicts values from $3^{\circ}$ to $9^{\circ} \mathrm{S}$ for slightly younger time (M21-M29, or Kimmeridgian).

\section{Reconstructions}

The paleomagnetic pole locations calculated from magnetic anomaly skewness (Fig. 6) can be used to make paleogeographic reconstructions of the Leg 129 drill site locations and the M-sequence magnetic lineation patterns with the following technique. First, the magnetic lineations for the mean age of each paleomagnetic pole location were digitized from Figure 1. The digitized magnetic lineations and Leg 129 sites can be rotated back to their original paleolatitudes and paleo-orientations by finding a set of rotation parameters (Euler poles) that will restore the present-day location of each paleomagnetic pole location to the geographic North Pole. This satisfies the axial geomagnetic dipole assumption for the skewness data. The location of each Euler pole is at latitude $=0^{\circ}$ and longitude $=$ APWP longitude $+90^{\circ}$. This point is $90^{\circ}$ along great circles from both the present-day paleomagnetic pole location and the North Pole (spin axis). Rotation about this Euler pole will restore the paleomagnetic pole location to the North Pole along a great circle path. The rotation angle is equal to the APWP colatitude. Since the paleomagnetic pole is also assumed to have moved with the Pacific plate since its origin, this same Euler pole rotation will restore Pacific plate features (magnetic lineations and drill sites) to their original paleolatitudes and paleo-orientations. As with any paleogeographic reconstruction utilizing paleomagnetic pole locations, paleolongitude cannot be determined. Thus, the paleolongitude axis on our paleogeographic reconstructions is not labeled.

Figures 7 and 8 show two different versions of the Early Cretaceous to Late Jurassic (122-155 Ma) paleogeographic reconstructions, Figure 7 by means of anomalous skewness in the lune intersection calculations, and Figure 8 without anomalous skewness, but with a

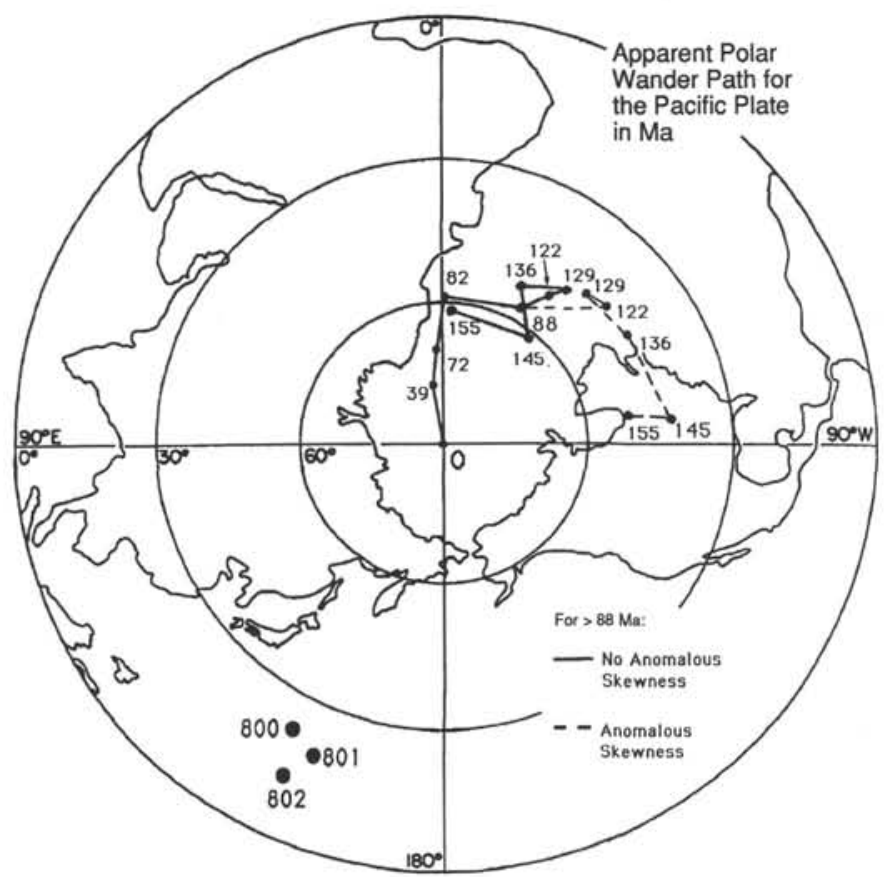

Figure 6. APWP for the Pacific plate based on seamounts from 39 to $88 \mathrm{Ma}$ and on magnetic lineations from 122 to $155 \mathrm{Ma}$. Seamount poles are from Sager and Pringle (1988) and the magnetic lineations poles are from Larson and Sager (this volume). Geological time scale calibration is from Kent and Gradstein (1985).

Stealth plate between the Pacific and Phoenix plates from M24 to M12. Both show the present-day locations of the Leg 129 sites and the M-lineation isochrons. Figure 8 shows the symmetric lineation pattern from M24 to M12 that would have resulted from the Stealth plate forming between the Pacific and Phoenix plates. Little, if any, of such a pattern has been identified in this area, making this suggestion speculative, but testable by future surveys.

Varying amounts of anomalous skewness were used by Larson and Sager (this volume) to improve all of the confidence lune intersections, so each of the five reconstructions are different in Figures 7 and 8 . However, very little anomalous skewness is necessary to optimize the intersections for M1 and M9, so these reconstructions are very similar for both solutions. Both of these solutions show the Pacific plate almost completely in the Southern Hemisphere, with the Leg 129 sites locations almost entirely between $20^{\circ}$ and $30^{\circ} \mathrm{S}$. Only a small amount of clockwise rotation of the Pacific plate has occurred since M1 and M9. Before M9, the two solutions diverge. The anomalous skewness solution requires an increasingly large rotational component of Pacific plate motion, most of which occurred before M9. Also, in that solution the Pacific plate was nearly bisected by the paleoequator in the Late Jurassic, although the Leg 129 sites lie on the half in the Southern Hemisphere, in accord with the sediment inclination data.

The Stealth plate solution uses only the Japanese and Hawaiian lineation skewness to calculate the Pacific plate paleomagnetic pole locations for M12, M18, and M24, because the Phoenix (Nauru Basin) lineations were forming on the Stealth-Phoenix plate boundary. In this solution the Pacific plate would have been even smaller than is usually supposed at M24. The Stealth plate would have expanded in size until approximately M10N when the Stealth-Pacific ridge died and the Phoenix lineations became of part of the Pacific plate. The Leg 129 drill sites would have formed very close to the paleoequator in the Middle to Late Jurassic. Very little plate rotation would have occurred in the Jurassic, in contrast to the solution that requires anomalous skewness. 


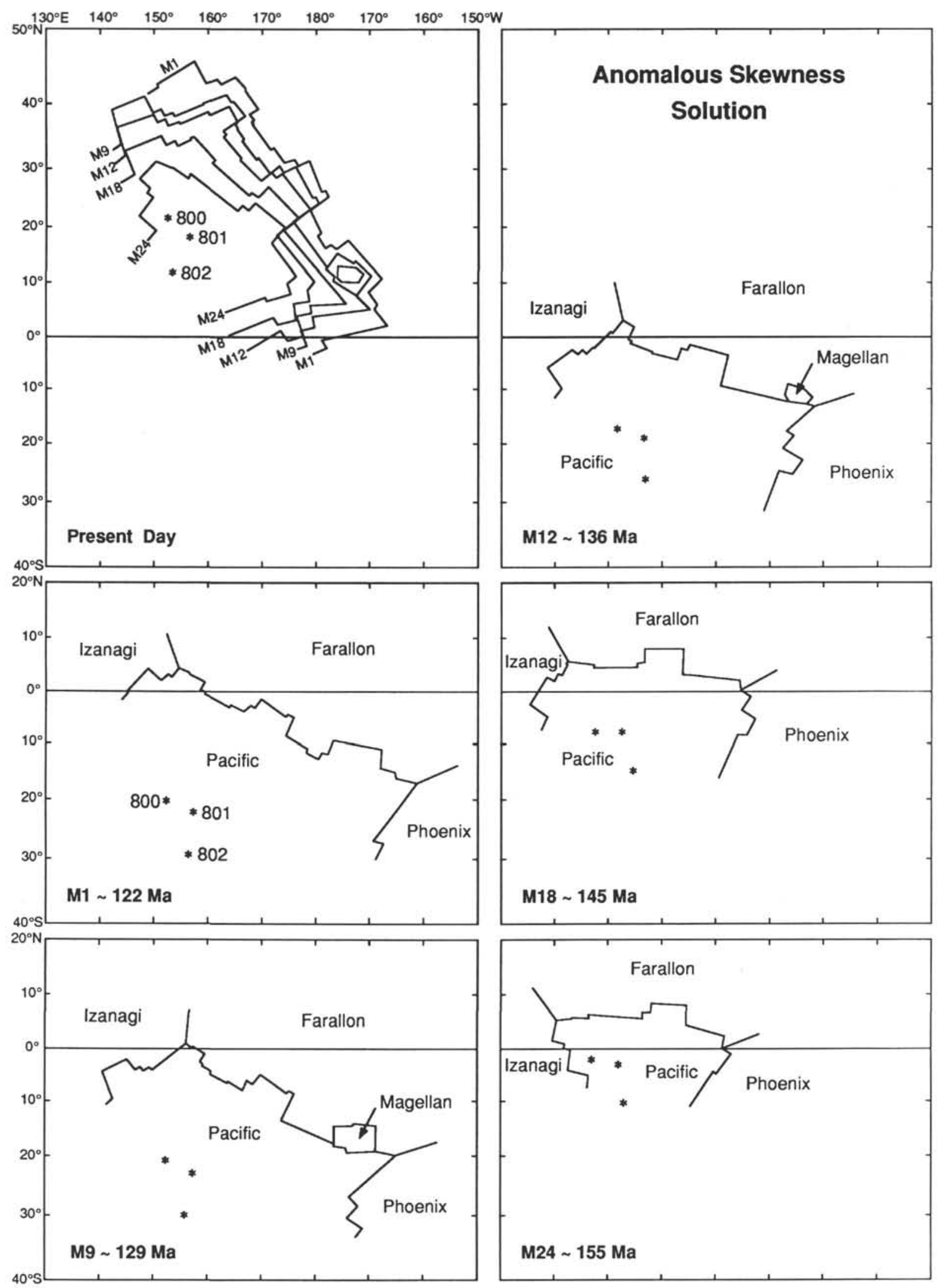

Figure 7. Paleogeographic reconstructions of selected western Pacific magnetic lineations (Larson and Sager, this volume) and Leg 129 drill sites calculated from Euler pole rotation parameters that will restore the "anomalous skewness" pole locations (from Fig. 6) to geographic north. Paleolongitude is not determined by this method. Geological time scale calibration is from Kent and Gradstein (1985). 

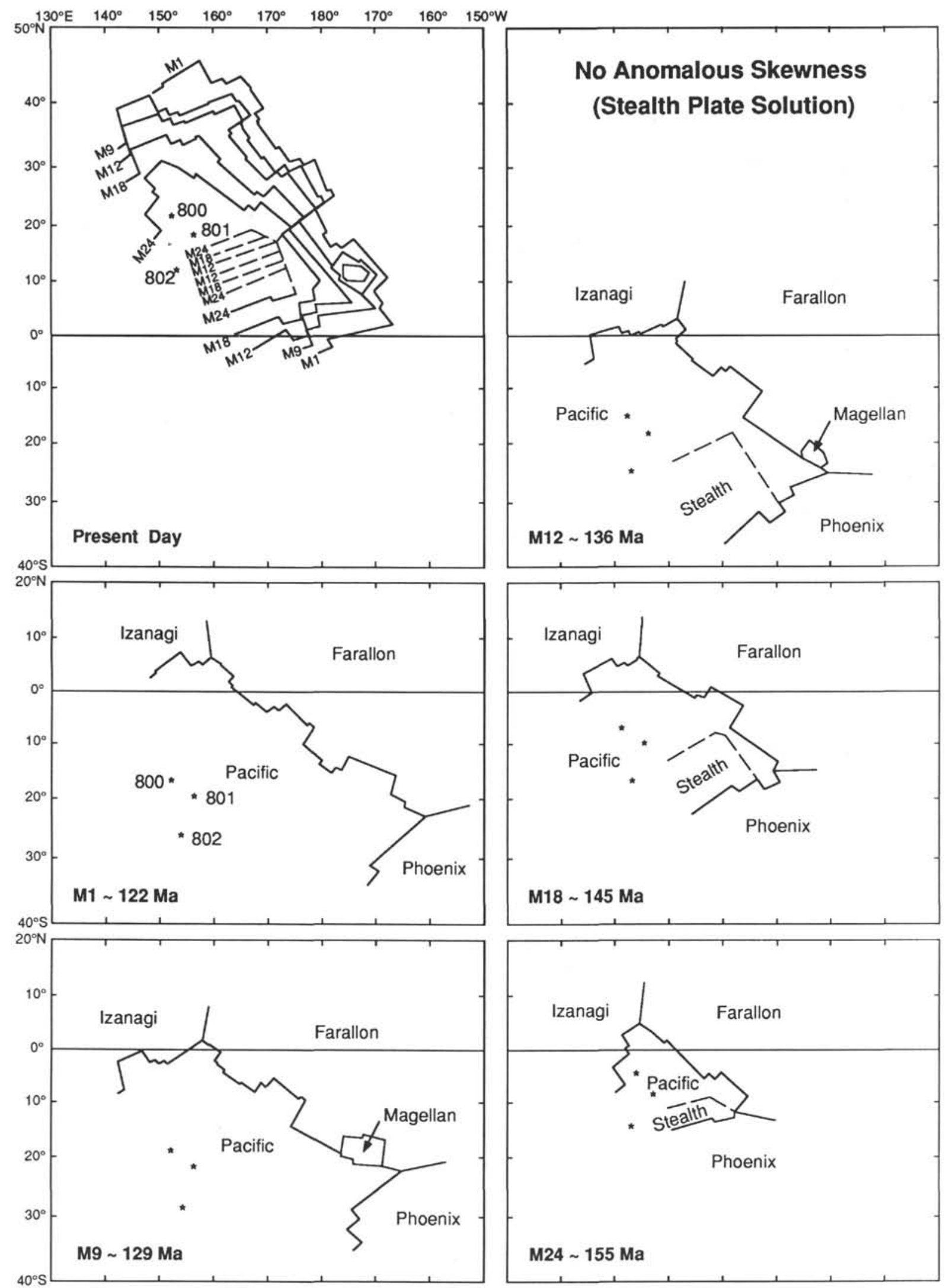

Figure 8. Paleogeographic reconstructions of selected western Pacific magnetic lineations (Larson and Sager, this volume) and Leg 129 drill sites calculated from Euler pole rotation parameters that will restore the "no anomalous skewness" pole locations (from Fig. 6) to geographic north. Paleolongitude is not determined by this method. Note the "Stealth plate" lineations predicted by this solution on the present-day chart. Geological time scale calibration is from Kent and Gradstein (1985). 


\section{LATE CRETACEOUS-EARLY CENOZOIC PALEOEQUATORIAL CROSSINGS}

Sediment inclination and paleoecology data from the Leg 129 drill sites can be used to mark the paleoequatorial crossings of these locations. These data can be compared with models of Pacific plate motion that are based on paleomagnetic poles from seamounts and on fixed hotspot models. The sediment inclination data indicate that Site 800 (Fig. 2) reached the paleoequator sometime during the late Cenomanian to Turonian-early Campanian. The Site 801 (Fig. 3) paleoequatorial crossing is not clearly indicated by the sediment inclinations, but appears to have been during the Santonian-Campanian. The Site 802 sediment inclination data are difficult to interpret. We discount apparent indications of an excursion across the paleoequator during the Santonian to late Campanian as due to drilling remanence imposed on a particularly susceptible lithology (left side of Fig. 4). The data above this interval appear reliable (right side of Fig. 4) and suggest a paleoequatorial crossing during the late Paleocene-early Eocene. These conclusions are all discussed in greater detail by Steiner and Wallick (this volume).

Paleontological data cannot produce a completely quantified paleolatitude history, but they can be used to identify assemblages characteristic of specific latitudinal belts. The studies conducted on the modern nannoplankton in the Pacific Ocean (e.g., Okada and Honjo, 1973; Roth and Berger, 1975; Geitzenauer et al., 1976; Roth and Coulbourn, 1982) show latitudinal patterns in the nannofloral composition as well as a strong influence of preservation. Selective dissolution only partially obscures the record of coccolith provinciality; an equatorial assemblage was detected between $10 \mathrm{~S}$ and $10 \mathrm{~N}$ and related to higher nutrient content and relatively cooler temperatures in the equatorial upwelling belt. The equator is marked by a narrow upwelling belt where calcareous nannofossils show a minimum in both abundance and diversity and biogenic sedimentation is dominated by radiolarians. Okada and Honjo (1973) further subdivide the equatorial belt into an equatorial-south zone $\left(10^{\circ} \mathrm{S}-\right.$ $\left.3^{\circ} \mathrm{S}\right)$ and equatorial-north zone $\left(3^{\circ} \mathrm{S}-5^{\circ} \mathrm{N}\right)$, suggesting that modern nannoplankton is sensitive to oceanographic changes. Likewise, the nannofloral distribution in the Cretaceous Pacific ocean seem to reflect the more fertile conditions of the paleoequatorial upwelling area.

Calcareous nannofossil assemblages and radiolarian abundances have been used as markers of paleoequatorial conditions by Erba (this volume). Mid-Cretaceous nannofossil taxa indicative of upwelling in the paleoequatorial belt were previously identified by Roth (1981) in the Pacific Ocean. In particular, Biscutum constans and Zygodiscus erectus show sharp increases in abundance in the paleoequatorial divergence area. Moreover, when approaching the upwelling belt, $B$. constans increases in abundance and reaches maximum values before $Z$ e erectus. This pattern may be interpreted as a differential response of nannofossil taxa to the environment. That is, $B$. constans is sensitive to high fertility in a mesotrophic condition, whereas $Z$. erectus is sensitive to higher fertility in a more eutrophic and cooler environment.

Major changes in nannofossil assemblage composition were observed at Sites 800 and 801 , where both high-fertility indicators reach the highest values in abundance in upper Albian to Cenomanian sediments and, at both sites, B. constans increases in abundance before $Z$. erectus. Increases in abundance of these taxa correspond to increases in radiolarians, which later become the dominant biogenic component. Calcareous nannofloras are first affected by dissolution and then apparently disappear. The changes in nannofossil assemblage composition might suggest an evolutionary trend or a response to temporal oceanwide fluctuations in fertility rather than the crossing of the paleoequatorial belt. However, such an increase of $B$. constans and $Z$. erectus has not been documented worldwide in Albian to Cenomanian sequences. On the contrary, the dominance of these fertility indicators is restricted to specific areas of the mid-Cretaceous oceans. In the Pacific basin, Roth (1981) documented that high abundances of $B$. constans and $Z$. erectus are diachronous and recorded only when sites are close to the paleoequatorial upwelling belt.
The stratigraphic differences in the curves of the higher fertility indicators between Sites 800 and 801 makes unlikely the possibility of an oceanwide change in fertility or an evolutionary trend.

Correlation with paleolatitudes computed from sediment inclination data (Figs. 9 and 10) indicates that at Sites 800 and 801, nannofossil assemblages showed a major change when the sites were at paleolatitudes between $10^{\circ} \mathrm{S}$ and $5^{\circ} \mathrm{S}$, and therefore seem to mark the southern edge of the paleoequatorial divergence. At paleolatitudes of less than $5^{\circ} \mathrm{S}$, presumably in the core of the upwelling zone, calcareous nannofossils disappear and are replaced by extremely abundant radiolarians. Site 800 reached the high-fertility belt during the late middle Albian (uppermost part of the $P$. columnata Zone) and the core of the paleoequatorial divergence during the Cenomanian. The paleoequatorial crossing is marked by the abrupt drop in nannofossil abundance and corresponding maximized abundance of radiolarians sometime between the Turonian to early Campanian. Site 801 approached the paleoequatorial upwelling belt during the late Albian $(E$. turriseiffelii Zone) and reached the inner part of the divergence during the Cenomanian. The paleoequatorial crossing is again marked by the abrupt drop in nannofossil abundance and the maximized abundance of radiolarians sometime between the Coniacian and the Campanian.

Data from Site 802 are less clear; here, calcareous nannofossils are abundant but poorly to moderately preserved. The high-fertility indicators $B$. constans and $Z$. erectus occur, but are never really abundant throughout the mid-Cretaceous interval, whereas radiolarians are very abundant. The high-fertility indices do not show blooms, and indeed, the site should have been at paleolatitudes south of the paleoequatorial upwelling zone when the same stratigraphic interval (E. turriseiffelii Zone) is compared with Sites 800 and 801 .

The background pelagic sediment stratigraphy reflects these changes in planktonic communities. At Site 800, the Albian through Turonian interval is represented by limestone and chert overlain by Campanian chert and porcellanite. Likewise, at Site 801, chalk, claystone, and porcellanite of Albian to Cenomanian age are overlain by chert and porcellanite of Coniacian through CampanianMaestrichtian age (Erba, this volume).

The ratio of nannofossil vs. radiolarian abundance can be biased by dissolution and by the poor recovery favoring the harder cherty lithology rather than the possibly interbedded soft chalk or limestone. Semiquantitative estimates of nannofossil and radiolarian abundance cannot entirely discern between preservation patterns and primary ecologic control. The type and magnitude of surface productivity are more constrained by estimates of the accumulation rates. Ogg et al. (this volume) analyzed several Pacific sites and suggested that during the Jurassic to Cretaceous interval biogenic silica accumulation rates depended mainly on paleolatitude. A pulse of high radiolarian productivity near the paleoequator resulted in a sharp increase of silica accumulation rate. The sedimentation was strongly controlled by this equatorial "silica bulge," which therefore could be used to deduce the equatorial transit of the Pacific plate (Lancelot and Larson, 1975; Lancelot, 1978; Ogg et al., this volume).

The paleoecology, sedimentology, and paleolatitude data derived from sediment inclinations show a consistent picture when compared to present-day equatorial productivity patterns in the Pacific. However, we argued earlier that the sediment inclinations are probably biased toward low values due to sediment compaction. Thus, we shall suggest in a later section that these data are indicative of a wider equatorial productivity zone in the Cretaceous than is present today, or a bias of that productivity zone toward the Southern Hemisphere.

The same technique that was used to rotate Leg 129 sites and magnetic lineations on the basis of magnetic anomaly skewness poles during the Early Cretaceous-Late Jurassic can also be used to rotate these sites to Cenozoic-Late Cretaceous paleolatitudes on the basis of paleomagnetic poles from seamounts (Figs. 11 and 12). These figures also show these same sites backtracked in accord with Pacific plate motion models of Lancelot and Larson (1975) and Duncan and Hargraves (1984), which are based on fixed Pacific hotspots. 


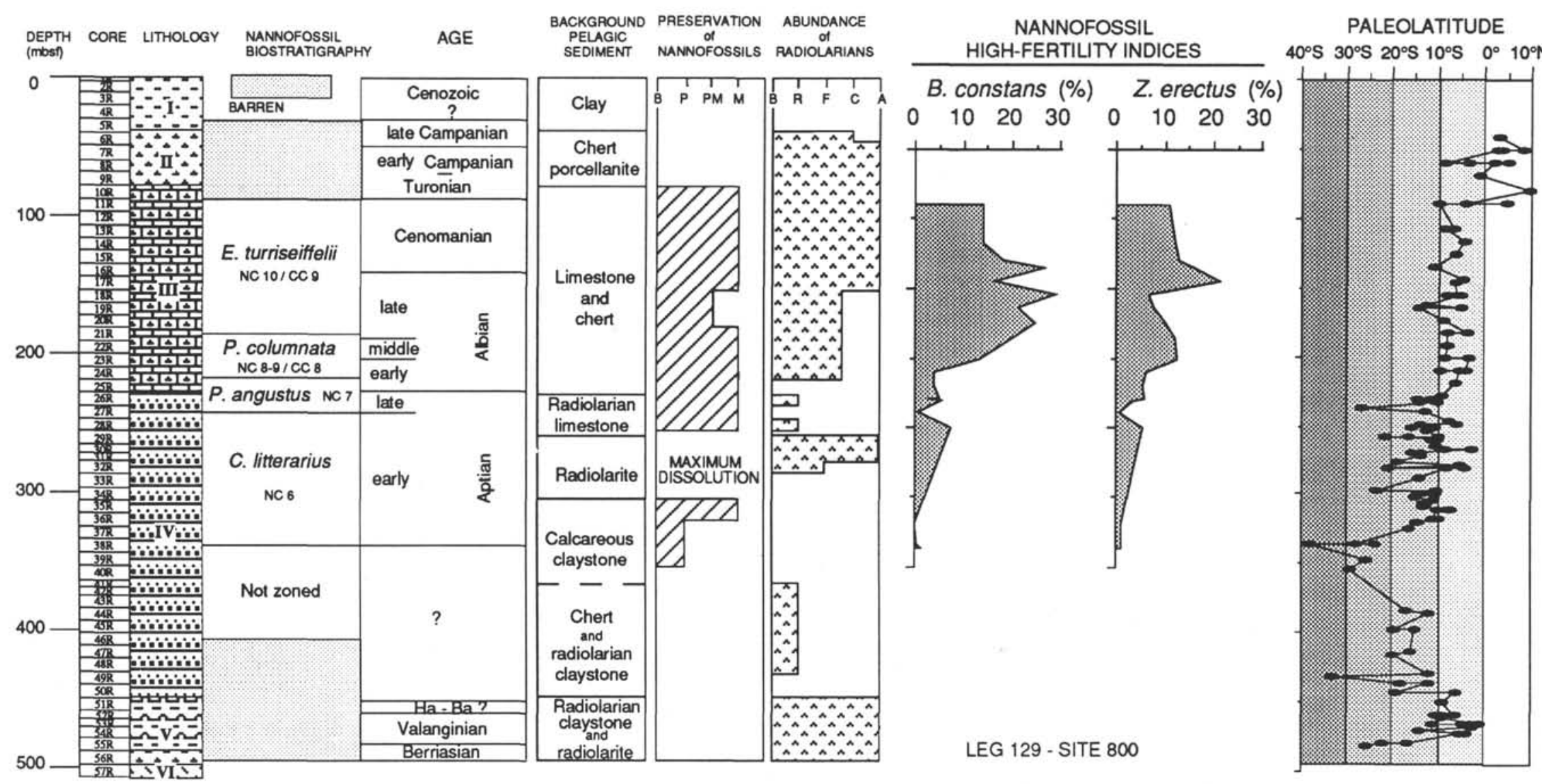

Figure 9. Changes in preservation of nannofloras and abundance of nannofossil fertility indices in the Aptian to Cenomanian interval of Site 800, from Erba (this volume). Distribution of radiolarians from Lancelot, Larson, et al. (1990), and paleolatitudes from Steiner and Wallick (this volume) and Figure 2. 
DEPTH CORE LITHOLOGY NANNOFOSSIL

AGE

(mbsf)

BIOSTRATIGRAPH

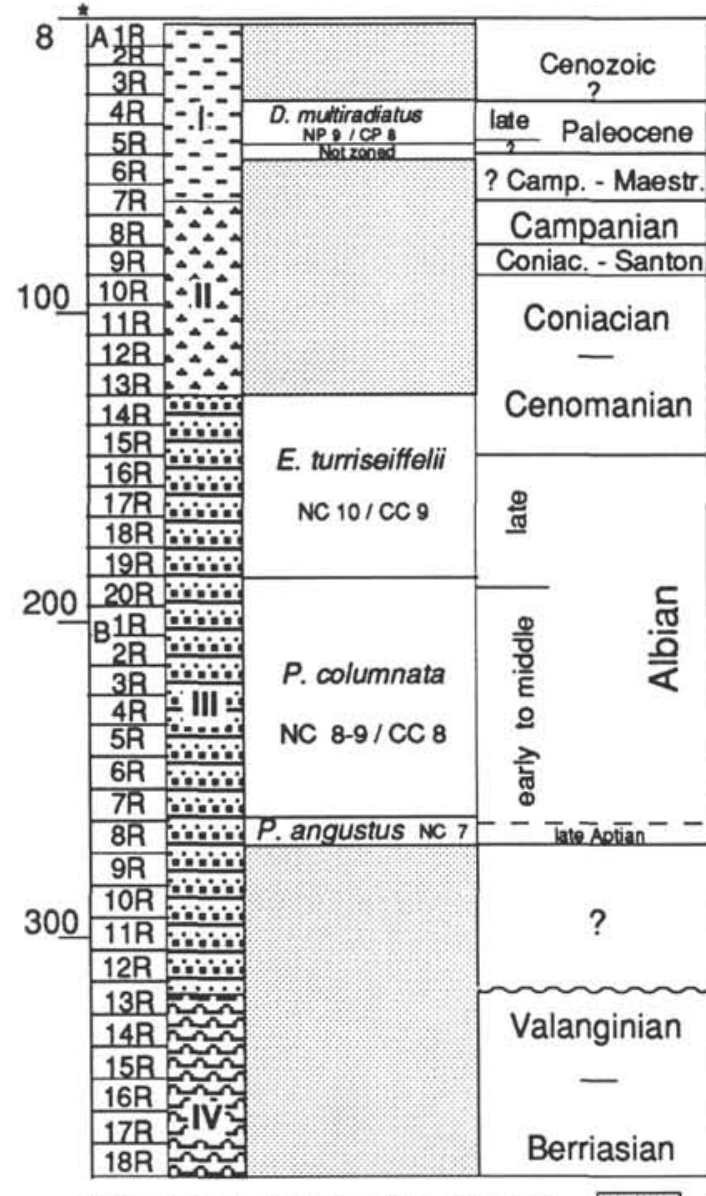

- No recovery between 0 and 8 mbsf.
BACKGROUND PRESERVATION ABUNDANCE PELAGIC NANIMENT NANNOFOSSILS RADIOLARIANS
SEDIS

Clay
Chert
porcellanite
porcellanite
annofossil
chalk-laystone
pannotossil
and
radiolarian
claystone

BARREN

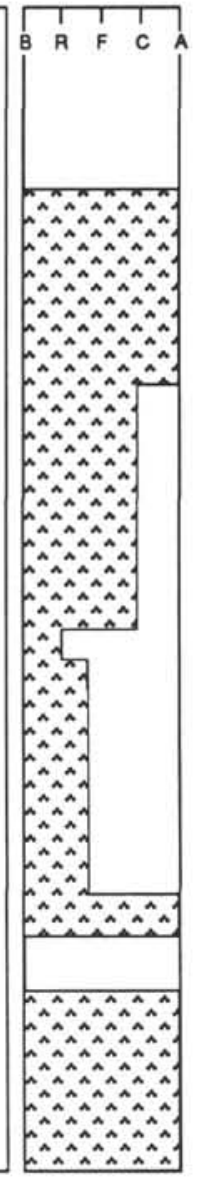

NANNOFOSSIL HIGH-FERTILITY INDICES

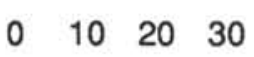

LEG 129 - SITE 801
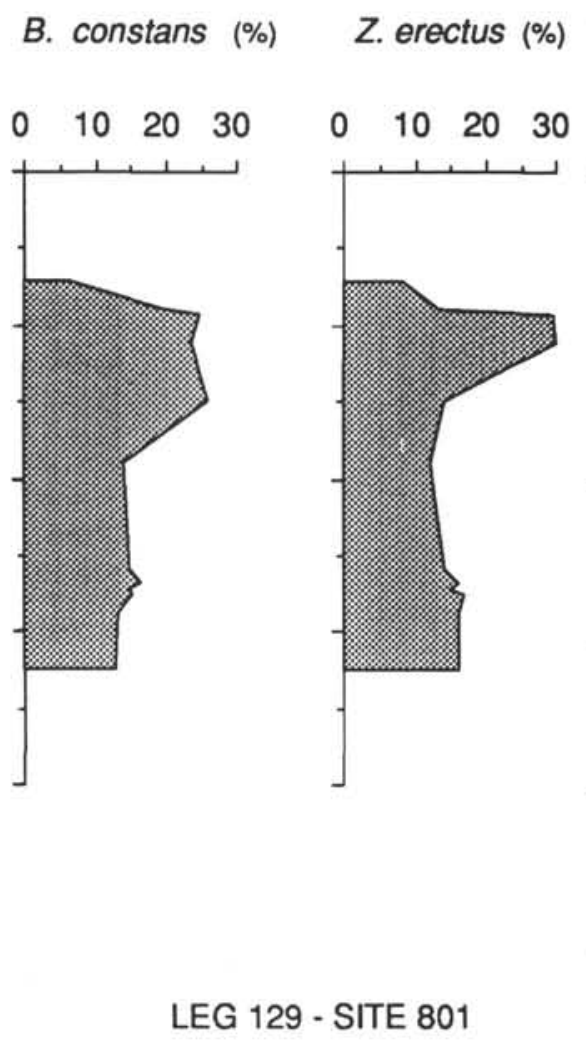

PALEOLATITUDE
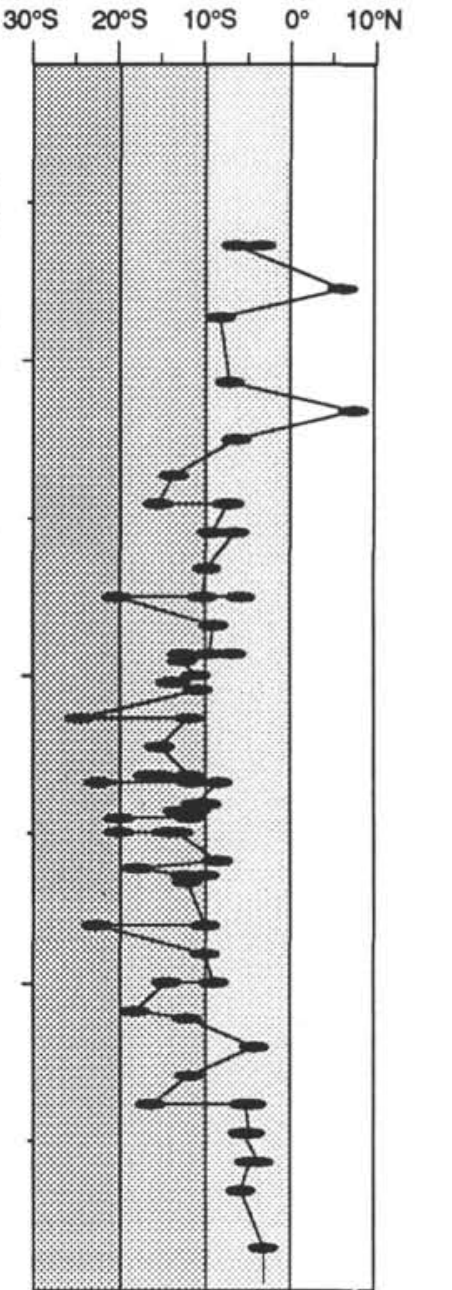

Figure 10. Changes in preservation of nannofloras and abundance of nannofossil fertility indices in the latest Aptian to Cenomanian interval of Site 801, from Erba (this volume). Distribution of radiolarians from Lancelot, Larson, et al. (1990), and paleolatitudes from Steiner and Wallick (this volume) and Figure 3. 


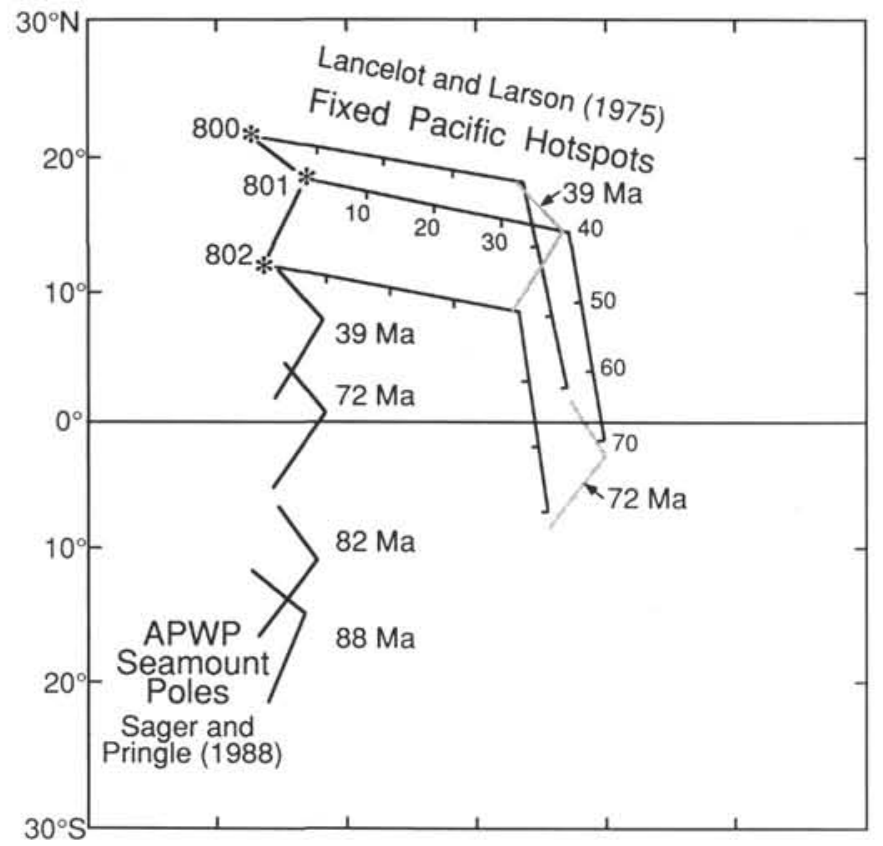

Figure 11. Paleolatitude reconstructions of Leg 129 sites (800, 801, and 802) calculated from Euler pole rotation parameters that will restore the 39-, 72-, 82-, and 88-Ma seamount pole locations (from Fig. 6) to geographic north (APWP seamount poles). Backtrack paths of Leg 129 sites (800, 801, and 802) calculated from the fixed hotspot model of Lancelot and Larson (1975) (fixed Pacific hotspots). The 39- and 72-Ma site locations are outlined on the backtrack paths for comparison with the seamount pole calculations.

Linear interpolation between the paleo-locations of sites based on seamount poles yields the following paleoequatorial crossing times: Site 800, $76 \mathrm{Ma}$ (late Campanian); Site 801, $73 \mathrm{Ma}$ (early Maestrichtian); Site 802, $49 \mathrm{Ma}$ (middle Eocene). These times are slightly later but generally compatible with the paleoequatorial crossing times suggested by the sediment inclination data. The crossing times of Sites 800 and 801 during the Campanian (or early Maestrichtian) seem generally later than those indicated by paleoecology. The paleoecology suggests crossing times ranging from Turonian to early Campanian for Site 800 and Coniacian to Campanian for Site 801 . However, the nannofossil fertility indices suggest these sites encountered the southern edge of the paleoproductivity zone during the middle to late Albian (101-96 Ma), so it is unlikely that the paleoequatorial crossing occurred much later than approximately the Santonian (87-84 Ma). Perhaps this is because the center of the paleoproductivity zone was slightly south of the geographic equator in the Cretaceous. The paleoproductivity zone might also have been expanded into a wider equatorial belt than at present.

\section{POSSIBLE TRUE POLAR WANDER DURING THE CENOZOIC}

Although both fixed hotspot models shown in Figures 11 and 12 contain solutions for Pacific plate motion to $125 \mathrm{Ma}$, we show only the parts of the models to $70-75 \mathrm{Ma}$, because no seamount chains in the Pacific have been dated beyond those ages. We view the earlier parts of these models as highly speculative. The parts of the models shown here are generally referred to as the "Hawaiian" $(0-40 \mathrm{Ma})$ and "Emperor" (40-70 or $75 \mathrm{Ma})$ rotations. There are some clear consistencies and inconsistencies apparent on Figures 11 and 12. In particular, the Lancelot and Larson (1975) fixed hotspot model is consistent with the seamount pole for $72 \mathrm{Ma}$, but not for $39 \mathrm{Ma}$, while just the converse is true for the Duncan and Hargraves (1984) fixed hotspot model.

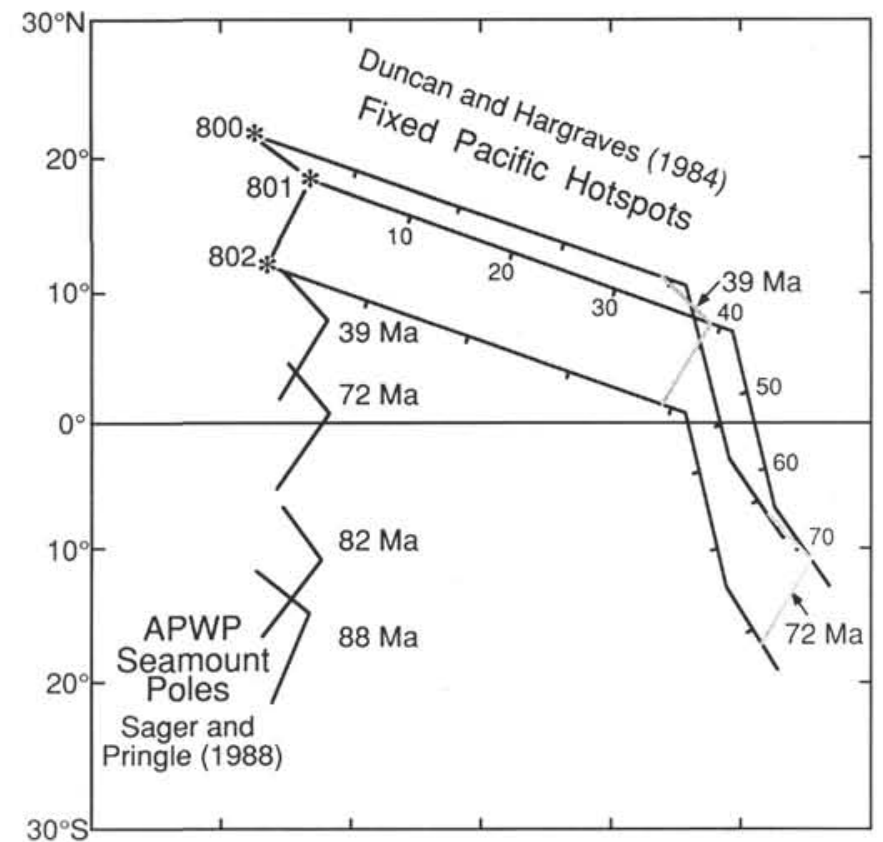

Figure 12. Paleolatitude reconstructions of Leg 129 sites $(800,801$, and 802$)$ calculated from Euler pole rotation parameters that will restore the 39-, 72-, $82-$, and 88-Ma seamount pole locations (from Fig. 6) to geographic north (APWP seamount poles). Backtrack paths of Leg 129 sites $(800,801$, and 802) calculated from the fixed hotspot model of Duncan and Hargraves (1984) (fixed Pacific hotspots). The 39- and 72-Ma site locations are outlined on the backtrack paths for comparison with the seamount pole calculations.

Both fixed hotspot models predict generally later (post-Campanian) paleoequatorial crossings for Sites 800 and 801 than suggested by the sediment inclinations or by the seamount poles, and considerably later than predicted by the paleoecology. This leads us to suspect the fixity of the Pacific hotspots. The hypothesis of true polar wander (TPW) questions the basic assumption of the fixed hotspot model (Hargraves and Duncan, 1973). A version of this hypothesis supposes that the entire solid shell of the Earth (the crust, mantle, and the hotspots contained within) sometimes undergoes a finite rotation, or "tumbling," with respect to the Earth's spin axis and its paleoequator (Andrews, 1985). Perhaps this is due to a change in the Earth's angular momentum resulting from a change in plate motion or mantle convection patterns. There is no evidence for TPW from the Hawaiian-Emperor seamount chains for at least the past 40 m.y. (Jackson et al., 1980), but Suiko Guyot ( 65 Ma) in the northern Emperor chain has a paleolatitude of $27^{\circ} \mathrm{N}$ based on remanent basalt inclinations (Kono, 1980; Jackson and others, 1980) in contrast to the present-day hotspot location of $19^{\circ} \mathrm{N}$. This implies that the Hawaiian hotspot moved south by $8^{\circ}$, sometime between 65 and $40 \mathrm{Ma}$. This is supported by the dominance of "bryozoan-algal" facies of carbonate sediments atop the Emperor guyots that grow today at temperate latitudes, as opposed to the "coral-algal" facies that characterize the present-day Hawaiian hotspot latitude (McKenzie et al., 1980; Schlanger and Konishi, 1966, 1975). The Reunion hotspot on the opposite side of the Earth from Hawaii has undergone a comparable amount of northward motion between 65 and $40 \mathrm{Ma}$, supporting the true polar wander hypothesis (Duncan, 1990). There may have been other episodes of TPW (Courtillot and Besse, 1987; Besse and Courtillot, 1991), but these cannot be resolved with our data.

It is generally supposed that this TPW episode occurred gradually over the majority of the 65-40-Ma interval, and indeed a few sediment inclination measurements give some support for that suggestion (Sager and Bleil, 1987). However, it is possible, if not likely, that these 
sediment inclinations are subject to the same inclination error (Tarduno, 1990) that we have detected in the sediment inclination data from Site 800 and 801 . Correction for this potential inclination error could result in the contrasting hypothesis that most of the TPW occurred near the end of that time interval.

We suggest that the entire $8^{\circ}$ of TPW occurred near the time of the Hawaiian-Emperor bend (41-43 Ma, Fig. 13) due to the "hard" collision of India and Africa/Arabia against Eurasia at that time (Duncan and Richards, 1991). This is coincident with the "hairpin turn" ( $180^{\circ}$ direction change) in the general worldwide TPW curve that Courtillot and Besse (1987) and Besse and Courtillot (1991) attribute to the same continental collision. We emphasize that current data sets cannot discriminate between sudden or gradual TPW between 65 and $40 \mathrm{Ma}$. Our suggestion of sudden TPW is based solely on the premise that it resulted from the worldwide plate velocity reorganization at $43 \mathrm{Ma}$. However, the sudden vs. gradual TPW hypotheses are testable by several independent techniques on material or areas that formed just before the supposed sudden TPW.

The effect of a sudden TPW "correction" on the fixed hotspot models (Figs. 11-13) can be visualized by imagining all of the pre-Hawaiian portions of the backtrack paths shifted $8^{\circ}$ north. This predicts a paleoequatorial crossing of Site 800 at $85 \mathrm{Ma}$ (Santonian) using the Lancelot and Larson (1975) model and 72 Ma (early Maestrichtian) using the Duncan and Hargraves (1984) model, compared with the Campanian predictions from sediment inclinations and seamount poles. The same TPW correction predicts a paleoequatorial crossing of Site 801 at $80 \mathrm{Ma}$ (Campanian) using the Lancelot and Larson (1975) model and $66 \mathrm{Ma}$ (late Maestrichtian) using the Duncan and Hargraves (1984) model, compared with the Campanian prediction from sediment inclinations and the early Maestrichtian prediction from seamount poles.

Thus, the TPW correction brings the hotspot models into general accord with the sediment inclination data and the seamount poles. However, the hotspot models and other existing data sets are not sufficiently precise to discriminate between the two models on the basis of predicted paleoequatorial crossing times. Other comparisons lead us to prefer a TPW-corrected version of the Duncan and Hargraves (1984) model over the Lancelot and Larson (1975) model. In particular, TPW correction of the pre-40-Ma portion of the Duncan and Hargraves (1984) model will tend to remove the discrepancy with the 72-Ma seamount pole, while preserving the concordance with the 39-Ma seamount pole.

\section{INTEGRATED PALEOLATITUDE HISTORY OF THE MESOZOIC PACIFIC}

Figure 13 shows a summary of the various data sets that constrain the paleolatitude history of the Jurassic-age portion of the Pacific plate. These data have been converted to the location of Site 801 which penetrated oceanic crust of Middle Jurassic (Bathonian-Cal-

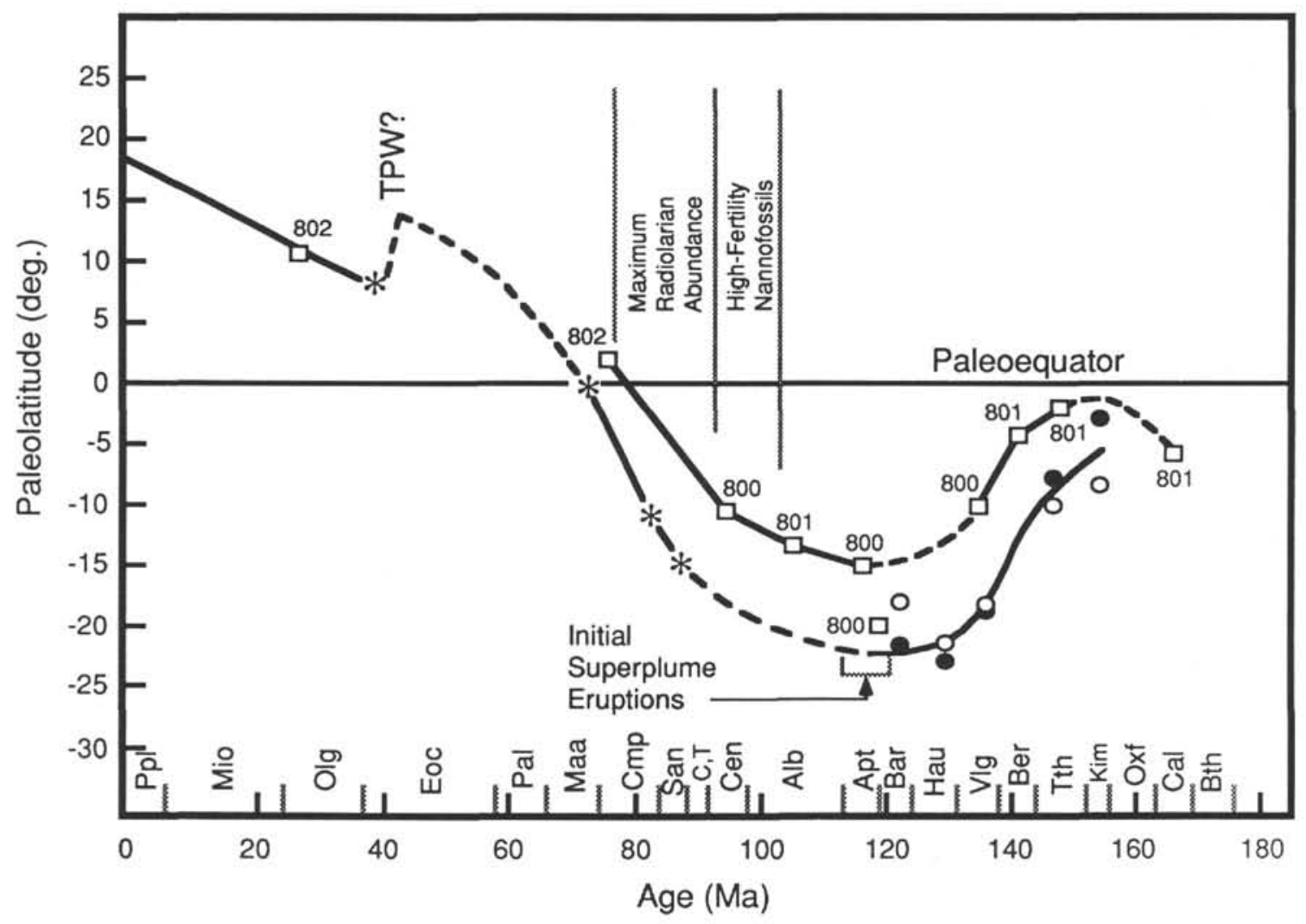

Figure 13. Possible paleolatitude histories for Site 801 from studies of seamount poles, magnetic anomaly skewness, sediment inclinations, basalt inclinations, paleoecology, and fixed hotspot models on Sites 800 and 801 in the Pigafetta Basin, western Pacific Ocean. Geological time scale calibration is from Kent and Gradstein (1985). Asterisks are seamount pole paleolatitudes (Sager and Pringle, 1988). Solid dots are magnetic anomaly skewness paleolatitudes utilizing anomalous skewness, and open dots correspond to no anomalous skewness solutions (Larson and Sager, this volume). Squares labeled 800, 801, and 802 are sediment inclination paleolatitudes taken from the numbered sites (Steiner and Wallick, this volume) and calibrated to the Site 801 location. "Maximum radiolarian abundance" indicates the time of crossing of the center of the high-productivity zone at or near the paleoequator, while "high-fertility nannofossils" indicates the time of crossing into the southern edge of that high-productivity zone (Erba, this volume). TPW indicates the true polar wander episode that we speculate occurred at $43-41 \mathrm{Ma}$. 
lovian) age. Two possible paleolatitude histories are shown for the Middle Jurassic through Cretaceous, one represented by the sediment inclination data that are in general accord with the present-day size and location of the equatorial high-productivity zone, and the other represented by the seamount poles and magnetic anomaly skewness data. The seamount poles and magnetic anomaly skewness data may provide a more accurate paleolatitude history because other studies have indicated sediment inclinations to be biased toward values that are shallower by comparison, and thus are indicative of lower paleolatitudes. Leg 129 sediment inclinations are also shallower than predicted by seamount or skewness poles. However, if the seamount and magnetic anomaly skewness data are the more accurate paleolatitude indicators, this implies a different geography than presently observed for the equatorial high-productivity zone of the mid-Cretaceous Pacific Ocean, at least in the Southern Hemisphere.

The paleolatitude curves shown in Figure 13 were constructed in the following manner. The sediment inclination data for the Leg 129 drill sites (Figs. 2-4) were scrutinized to isolate the most precise and consistent data for sequential time periods, and then averaged over these short intervals ( 5-10 m.y.). If the data were from Sites 800 or 802 , the averaged paleolatitude was converted to the location of Site 801. Eight of the nine resulting data points present an internally consistent picture, showing consistently lower paleolatitudes than the seamount pole and magnetic anomaly skewness data with one exception. The Site 800 sediment inclination, showing a $20^{\circ} \mathrm{S}$ paleolatitude with a probable early Aptian age, is a substantially higher paleolatitude estimate than any of the other sediment data, and is in close accord with the paleolatitude curve based on the seamount poles and magnetic anomaly skewness. This sequence is barren of datable fossils, but is a coarse-grained, basal turbidite that we suspect represents the onset of Aptian volcanism at Site 800. The extremely coarse-grained nature of the sequence may have prevented postdepositional inclination shallowing in this sequence.

The onset time of "high-fertility nannofossils" is marked by the late Albian increase in abundance B. constans observed at Site 801 (Fig. 10), which is supported by the same increase at Site 800 in the middle Albian. The upper limit of high-fertility nannofossils is placed in the late Cenomanian when both $B$. constans and Z. erectus disappeared and were replaced by the maximum abundance of radiolarians. Radiolarians persist in maximum abundance until the late Campanian at both sites, and presumably mark the core of the equatorial current divergence zone.

The southern of the two paleolatitude histories (Fig. 13) is outlined for the Late Cretaceous by the seamount poles of Sager and Pringle (1988) at $39,72,82$, and $88 \mathrm{Ma}$ (Figs. 11 and 12). It is continued into the Early Cretaceous and Late Jurassic with the magnetic anomaly skewness poles. The curve drawn through these data in Figure 13 is an approximate average of the poles with and without anomalous skewness, as well as the Site 800 sediment inclination in the early Aptian.

A relatively consistent relationship exists between the two possible paleolatitude histories. The sediment inclinations always indicate lower paleolatitudes than the seamount poles and skewness data with the exception of the basal turbidites, probably deposited at the Barremian/ Aptian boundary. This discrepancy may be accentuated in the Late Cretaceous due to the slight mismatch in paleoequatorial crossing times in the two paleolatitude histories. There is a tendency for this discrepancy to increase at higher latitudes and decrease near the paleoequator in the Late and mid-Cretaceous in general accord with the relationships observed by King (1955) and Tarduno (1990). The possibility of anomalous skewness in the Late Jurassic and Early Cretaceous does not allow such detailed resolution for the earlier history. We prefer the paleolatitude history outlined by the seamount poles and magnetic anomaly skewness for reasons discussed above, but this implies that fertility zone distributions were quite different in the Cretaceous Pacific from today. The late Albian increase in highfertility nannofossil abundances suggests that the southern edge of the Pacific equatorial fertility belt extended to $15^{\circ}-20^{\circ} \mathrm{S}$ during the middle Cretaceous. This might have resulted from the entire equatorial current system being asymmetrically displaced toward the Southern Hemisphere at that time, but this seems unlikely given the expanded size, and thus unrestricted nature, of the Cretaceous Pacific. A more likely possibility is that the equatorial current system of the mid-Cretaceous Pacific was broader and less focussed than it is today, giving rise to a generally broader equatorial productivity zone.

The southward to northward turnaround in Pacific plate motion occurred sometime from Hauterivian to Aptian time, perhaps near the Aptian/Barremian boundary. Present-day variations in plate motion rates and directions are thought to be due mainly to rearrangements of subduction zones that provide the driving forces for rapid plate motion. However, what we know of Mesozoic subduction from the geologic record of the rim of the Pacific Basin is that subduction was generally continuous since the Jurassic in the American Cordillera and in Japan (Hilde et al., 1977), while it was consistently absent on the northern margin of Australia (Powell, 1976). Thus, it is unlikely that changes in the subduction zone driving forces caused the change in direction of Pacific plate motion.

This change in direction is essentially coincident with the onset of the voluminous eruptions of the mid-Cretaceous superplume episode (Larson, 1991). We suggest a casual relationship between the superplume episode and the north-south turnaround in Pacific plate motion with the following mechanisms. Prior to the turnaround in direction, a lithospheric swell formed above the rising, but not yet erupting pulse of plume material, causing the Pacific plate to slow its southward motion as it was being forced to move "uphill." This braking action was then replaced by ridge-push and asthenosphericdrag forces after the mid-Cretaceous eruptions began. The ridgepush force (Forsyth and Uyeda, 1975) was simply the same previous braking action in reverse gear. The asthenosphere drag force resulted from the majority of the rising plume material flowing radially away from the main eruption area just beneath the lithosphere/asthenosphere boundary (Bercovici et al., 1989; Glatzmaier et al., 1990), which tended to drag the overlying plate(s) in those flow directions (Ricard and Vigny, 1989).

Both of these mechanisms are in accord with the gradual change in Pacific plate motion from south to north. Southward Pacific plate motion slowed over a 10-15-m.y. period in the Early Cretaceous prior to the mid-Aptian. We speculate that this resulted from a lithospheric swell or bulge that formed above the rising plume material, which we assume was centered on the area of the most voluminous of the initial eruptions, the Early Cretaceous location of the Ontong-Java Plateau (Tarduno et al., 1991). The southward motion of the Pacific plate would have slowed as it attempted to move up the north side of this swell forming on the southern side of the Early Cretaceous Pacific plate. Two lines of thought have evolved over the "rise time" of the mid-Cretaceous plume material (Larson and Olson, 1991). If new plumes formed and rose from the core-mantle boundary (CMB), the rise time might have been $\sim 30 \mathrm{~m}$.y. Conversely, if the mid-Cretaceous pulse utilized existing plume conduits, it could rise as conduit-wave "solitons," in as little as 5-10 m.y. Neither rise time estimate is particularly quantitative, and thus the "braking time" of the Pacific plate is an uncertain way to discriminate between these two mantle plumbing processes. Also, the initial slow down could have resulted from the Pacific plate drifting south and encountering the pre-middle Cretaceous swell that resulted from Early Cretaceous hotspots acting as mantle conduits for the subsequent superplume episode.

After the pulse of plume material had ascended into the upper mantle, it melted a small equivalent fraction $(1 \%-10 \%)$ of the overlying lithosphere (Sleep, 1990) that erupted onto the seafloor. Almost all of the rising plume material was turned aside as it encountered the underside of the strong lithospheric lid. This material was recycled by less focused convection into the lower mantle. The majority of this material probably turned and flowed just below the base of the lithosphere along the zone of minimum viscosity within the asthenosphere. Viscous coupling with the lithosphere resulted in a force that tended to 
drag the overlying lithospheric plates along with the asthenospheric flow. Since most of the mid-Cretaceous Pacific plate lay north of the main eruption area of the Ontong-Java Plateau, the net asthenospheric drag force on the Pacific plate would have been toward the north. Although very little net northward motion occurred in the first 10-15 m.y. after the initial mid-Cretaceous eruptions, such Pacific plate motion was underway by the late Albian or Cenomanian. Once started, the northward motion increased rapidly, possibly due to a more northerly direction of overall plate motion, and resulted in approximately $100 \mathrm{~km} / \mathrm{m}$.y. of northward motion during the Late Cretaceous.

\section{CONCLUSIONS}

1. The Pacific plate had its origin as a small plate, perhaps of microplate dimensions, at equatorial, southern paleolatitudes during the Middle Jurassic. Sediment inclination data indicate near-equatorial paleolatitudes for the Pacific plate during the Middle and Late Jurassic.

2. Sediment inclination and magnetic anomaly skewness data both indicate southward drift of the Pacific plate from the Kimmeridgian until the Aptian, with the skewness data consistently indicating higher southern paleolatitudes, probably due to inclination shallowing in the sediment data. Site 801 reached a maximum paleolatitude of $22^{\circ} \mathrm{S}$ during the Aptian according to the skewness data, $40^{\circ}$ south of its present-day location.

3. The reversal in southward to northward motion of the Pacific plate probably was in response to the changing mantle dynamics of the mid-Cretaceous superplume episode. A lithospheric swell that formed prior to the mid-Cretaceous eruptions stopped southward motion of the Pacific plate, and northward motion was initiated by drag forces in the asthenosphere flowing radially away from the main eruption area.

4. Sediment inclination and seamount pole data both indicate northward drift of the Pacific plate during the Late Cretaceous, with the sediment inclination data indicating a paleoequatorial crossing of Site 801 during the Campanian and the seamount pole data indicating the crossing at about the Campanian/Maestrichtian boundary.

5. Paleoecology indices suggest that Site 801 reached the southern edge of the paleoecological high-productivity zone during the late Albian at $15^{\circ}-20^{\circ} \mathrm{S}$ paleolatitude, as indicated by an interpolation between the oldest seamount pole and the youngest skewness pole. Site 801 then crossed into the core of the paleoecological high-productivity zone during the late Cenomanian at $10^{\circ}-15^{\circ} \mathrm{S}$ paleolatitude, as indicated by the oldest seamount pole data.

6 . These high-fertility indices and paleolatitudes suggest that the geography of the Cretaceous high-productivity zone was different than it is today. Either the entire paleoequatorial productivity zone was shifted south relative to the Cretaceous equator, or more likely, this high-productivity zone was more expanded and diffuse than at present.

7. The Pacific plate continued to move north through the early Tertiary until $43 \mathrm{Ma}$, at which time, we speculate, the plate experienced $8^{\circ}$ of retrograde southward motion due to sudden true polar wander resulting from the impact of the Indian plate against Asia. The Pacific plate has moved in a northwesterly direction parallel to the Hawaiian seamount chain for the past $41 \mathrm{Ma}$, and continues to do so at present.

\section{ACKNOWLEDGMENTS}

We take this last opportunity to thank again the people from JOIDES, ODP/TAMU, and the SEDCO/BP 471 who helped to make Leg 129 a success and the Jurassic Pacific a reality. We acknowledge discussions and reviews from T. Bralower, R. A. Duncan, J. G. Ogg, I. Premoli Silva, P. H. Roth, W. W. Sager, J. A. Tarduno, B. P. Wallick, W. Wei, E. L. Winterer, and the late S. O. Schlanger. Larson and Steiner received support from the U.S. National Science Foundation through JOI/USSAC, and Erba received support from the Italian Consiglio Nazionale della Ricerche.

\section{REFERENCES}

Andrews, J. A., 1985. True polar wander: an analysis of Cenozoic and Mesozoic paleomagnetic poles. J. Geophys. Res., 90:7737-7750.

Anson, G. L., and Kodama, K. P., 1987. The effects of compaction on a synthetic PDRM. Geophys. J. R. Astron. Soc., 88:673-692.

Arason, P., and Levi, S., 1986. Inclination shallowing recorded in some deep sea sediments. Eos, 67:916.

Arthur, M. A., Dean, W. A., and Schlanger, S. O., 1985. Variations in the global carbon cycle during the Cretaceous related to climate, volcanism, and changes in atmospheric $\mathrm{CO}_{2}$. In Sundquist, E. T., and Broecker, W. S. (Eds.), The Carbon Cycle and Atmospheric $\mathrm{CO}_{2}$ : Natural Variations Archean to Present. Am. Geophys. Union, Geophys. Monogr., 32:504-529.

Bercovici, D., Schubert, G., and Glatzmaier, G. A., 1989. Three dimensional spherical models of convection in the Earth's mantle. Science, 244:950-955.

Besse, J., and Courtillot, V., 1991. Revised and synthetic apparent polar wander paths of the African, Eurasian, North American, and Indian plates, and true polar wander since 200 Ma. J. Geophys. Res., 96:4029-4050.

Blow, R. A., and Hamilton, N., 1978. Effect of compaction on the acquisition of a detrital remanent magnetization in fine grained sediments. Geophys. J., 52:13-23.

Cande, S. C., and Kent, D. V., 1985. Comment on "Tectonic rotations in extensional regimes and their paleomagnetic consequences for ocean basalts by K. L. Verosub and E. M. Moores." J. Geophys. Res., 90:4647-4651.

Celaya, M. A., and Clement, B. M., 1988. Inclination shallowing in deep sea sediments from the North Atlantic. Geophys. Res. Lett., 15:52-55.

Courtillot, V., and Besse, J., 1987. Magnetic field reversals, polar wander, and core-mantle coupling. Science, 237:1140-1147.

Duncan, R. A., 1990. The volcanic record of the Réunion hotspot. In Duncan, R. A., Backman, J., Peterson, L. C., et al., Proc. ODP, Sci. Results, 115: College Station, TX (Ocean Drilling Program), 3-10.

Duncan, R. A., and Hargraves, R. B., 1984. Plate tectonic evolution of the Caribbean region in the mantle reference frame. In Bonini, W. E. et al. (Eds.), The Caribbean-South American Plate Boundary and Regional Tectonics. Mem.-Geol. Soc. Am., 162:81-93.

Duncan, R. A., and Richards, M. A., 1991. Hotspots, mantle plumes, flood basalts, and true polar wander. Rev. Geophys., 29:31-50.

Forsyth, D., and Uyeda, S., 1975. On the relative importance of driving forces of plate motion. Geophys. J. R. Astron. Soc., 43:163-200.

Francheteau, J., Harrison, C.G.A., Sclater, J. G., and Richards, M. L., 1970. Magnetization of Pacific seamounts: a preliminary polar curve for the northeastern Pacific. J. Geophys. Res., 75:2035-2061.

Geitzenauer, K. R., Roche, M. B., and McIntyre, A., 1976. Modern Pacific coccolith assemblages: derivation and application to late Pleistocene paleotemperature analyses. Mem.-Geol. Soc. Am., 145:423-448.

Glatzmaier, G. A., Schubert, G., and Bercovici, D., 1990. Chaotic, subductionlike downflows in a spherical model of convection in the Earth's mantle. Nature, 347:274-277.

Gordon, R. G., 1990. Test for bias in paleomagnetically determined paleolatitudes from Pacific Plate Deep Sea Drilling Project sediments. J. Geophy. Res., 95:8397-8404.

Hall, F. R., and Kodama, K. P., 1983. The effects of consolidometer tests on the ARM of a wet sediment. Eos, 64:219.

Handschumacher, D. W., Sager, W. W., Hilde, T.W.C., and Bracey, D. R., 1988. Pre-Cretaceous tectonic evolution of the Pacific plate and extension of the geomagnetic polarity reversal time scale with implications for the origin of the Jurassic "Quiet Zones." Tectonophysics, 155:365-380.

Hargraves, R. B., and Duncan, R. A., 1973. Does the mantle roll? Nature, $245: 361-363$

Harrison, C.G.A., Jarrard, R. D., Vacquier, V., and Larson, R. L., 1975. Paleomagnetism of Cretaceous Pacific seamounts. Geophys. J. R. Astron. Soc., 42:859-882

Hilde, T.W.C., Isezaki, N., and Wageman, J. M., 1976. Mesozoic sea-floor spreading in the North Pacific. In Sutton, G. H., Manghnani, M. H., and Moberly, R. (Eds.), The Geophysics of the Pacific Ocean Basin and Its Margin. Am. Geophys. Union, Geophys. Monogr., 19:205-226.

Hilde, T.W.C., Uyeda, S., and Kroenke, L., 1977. Evolution of the western Pacific and its margin. Tectonophysics, 38:145-165.

Jackson, E. D., Koizumi, I., Dalrymple, G. B., Clague, D. A., Kirkpatrick, R. J., and Greene, H. G., 1980. Introduction and summary of results from DSDP Leg 55, The Hawaiian-Emperor hot-spot experiment. In Jackson, E. D., Koizumi, I., et al., Init. Repts. DSDP, 55: Washington (U.S. Govt. Printing Office), 5-31. 
Kent, D. V., and Gradstein, F. M., 1985. A Cretaceous and Jurassic geochronology. Geol. Soc. Am. Bull., 96:1419-1427.

King, R. F., 1955. The remanent magnetization of artificially deposited sediments. Mon. Notes Roy. Astron. Soc. Geophys. Suppl, 7:115-134.

Kono, M., 1980. Paleomagnetism of DSDP Leg 55 basalts and implications for the tectonics of the Pacific plate. In Jackson, E. D., Koizumi, I., et al., Init. Repts. DSDP, 55: Washington (U.S. Govt. Printing Office), 737-752.

Lancelot, Y., 1978. Relations entre evolution sedimentaire et tectonique de la plaque Pacifique depuis le Cretace Inferieur. Mem. Soc. Geol. Fr, 134:1-40.

Lancelot, Y., and Larson, R. L., 1975. Sedimentary and tectonic evolution of the northwestern Pacific. In Larson, R. L., Moberly, R., et al., Init. Repts. DSDP, 32: Washington (U.S. Govt. Printing Office), 925-940.

Lancelot, Y., Larson, R. L., et al., 1990. Proc. ODP, Init. Repts., 129: College Station, TX (Ocean Drilling Program).

Larson, R. L., 1976. Late Jurassic and Early Cretaceous evolution of the western Central Pacific Ocean. J. Geomagn. Geoelectr., 28:219-236.

- 1991. Latest pulse of earth: evidence for a mid-Cretaceous superplume. Geology, 19:547-550.

Larson, R. L., and Chase, C. G., 1972. Late Mesozoic evolution of the western Pacific Ocean. Geol. Soc. Am. Bull., 83:3627-3644.

Larson, R. L., and Lowrie, W., 1975. Paleomagnetic evidence for motion of the Pacific plate from Leg 32 basalts and magnetic anomalies. In Larson, R. L., Moberly, R., et al., Init. Repts. DSDP, 32: Washington (U.S. Govt. Printing Office), 571-577.

Larson, R. L., and Olson, P., 1991. Mantle plumes control magnetic reversal frequency. Earth Planet. Sci. Lett., 107:437-447.

Mammerickx, J., and Sharman, G. F., 1988. Tectonic evolution of the North Pacific during the Cretaceous quiet period. J. Geophys. Res., 93:3009-3024.

McKenzie, J., Bernoulli, D., and Schlanger, S. O., 1980. Shallow-water carbonate sediments from the Emperor Seamounts: their diagenesis and paleogeographic significance. In Jackson, E. D., Koizumi, I., et al., Init. Repts. DSDP, 55: Washington, D.C. (U.S. Govt. Printing Office), 415-462.

Nankanishi, M., Tamaki, K., and Kobayashi, K., 1989. Mesozoic magnetic anomaly lineations and seafloor spreading history of the northwestern Pacific. J. Geophys. Res., 94:15437-15462.

Nankanishi, M., Tamaki, K., and Kobayashi, K., in press. Magnetic anomaly lineations from Late Jurassic to Early Cretaceous in the west-central Pacific Ocean. Geophys. J. Int.

Okada, H., and Honjo, S., 1973. The distribution of oceanic coccolithophorids in the Pacific. Deep-Sea Res. Part A, 20:355-374.

Powell, D. E., 1976. The geological evolution of the continental margin off Northwest Australia. APEA J., 26:13-23.

Ricard, Y., and Vigny, C., 1989. Mantle dynamics with induced plate tectonics. J. Geophys. Res., 94:17543-17559.

Roth, P. H., 1981. Mid-Cretaceous calcareous nannoplankton from the central Pacific: Implications for paleoceanography. In Thiede, J., Vallier, T. L., et al., Init. Repts. DSDP, 62: Washington (U.S. Govt. Printing Office), $471-489$.

-1986. Mesozoic palaeoceanography of the North Atlantic and Tethys Oceans. In Summerhayes, C. P., and Shackleton, N. J. (Eds.), North Atlantic Palaeoceanography. Geol. Soc. Spec. Publ. London, 21:299-320.

1989. Ocean circulation and calcareous nannoplankton evolution during the Jurassic and Cretaceous. Palaeogeogr., Palaeoclimatol., Palaeoecol., 74:111-126.
Roth, P. H., and Berger, W. H., 1975. Distribution and dissolution of coccoliths in the south and central Pacific. In Sliter, W. V., Be, A.W.H., and Berger, W. H. (Eds.), Dissolution of Deep-sea Carbonates. Spec. Publ. Cushman Found. Foraminifera Res., 13:87-113.

Roth, P. H., and Coulbourn, W. T., 1982. Floral and solution pattern of coccoliths in surface sediments of the North Pacific. Mar. Micropaleontol., $7: 1-52$.

Sager, W. W., and Bleil, U., 1987. Latitudinal shift of Pacific hotspots during the late Cretaceous and early Tertiary. Nature, 326:488-490.

Sager, W. W., and Pringle, M. S., 1988. Mid-Cretaceous to Early Tertiary apparent polar wander path of the Pacific plate. J. Geophys. Res., 93:11753-11771.

Schlanger, S. O., Jenkyns, H. C., and Premoli Silva, I., 1981. Volcanism and vertical tectonics in the Pacific Basin related to global Cretaceous transgressions. Earth Planet. Sci. Lett., 52:435-449.

Schlanger, S. O., and Konishi, K., 1966. Contrasting bryozoan content of Plio-Pleistocene to present day carbonates from Guam, Mariana Islands and Kikai-Jima, Ryukyu Islands, and its regional implications. Proc. 11th Pac. Sci. Congr., Tokyo, Abstract No. 35.

, 1975. The geographic boundary between the coral-algal and the bryozoan-algal limestone facies: a paleolatitude indicator. Theme I, Indicateurs Sedimentol. IXme Congres Int. Sedim., Nice, France, 187-190.

Shipboard Scientific Party, 1986. Site 462. In Moberly, R., Schlanger, S. O., et al., Init. Repts. DSDP, 89: Washington (U.S. Govt. Printing Office), $157-211$.

Sleep, N. A., 1990. Hotspots and mantle plumes: some phenomonology. $J$. Geophys. Res., 95:6715-6736.

Steiner, M. B., 1981. Paleomagnetism of the igneous complex, Site 462. In Larson, R. L., Schlanger, S. O., et al., Init. Repts. DSDP, 61: Washington (U.S. Govt. Printing Office), 717-729.

Tamaki, K., and Larson, R. L., 1988. Mesozoic tectonic history of the Magellan microplate in the western Pacific. J. Geophys. Res., 93:2857-2874.

Tarduno, J. A., 1990. Absolute inclination values from deep sea sediments: a reexamination of the Cretaceous Pacific record. Geophys. Res. Lett. 17:101-104.

Tarduno, J. A., Sliter, W. V., Kroenke, L., Leckie, M., Mayer, H., Mahoney, J. J., Musgrave, R., Storey, M., and Winterer, E. L., 1991. Rapid formation of Ontong-Java Plateau by Aptian mantle plume volcanism. Science, 254:399-403.

Thierstein, H. R., 1979. Paleoceanographic implications of organic carbon and carbonate distribution in Mesozoic deep sea sediments. In Talwani, M., Hay, W., and Ryan, W.B.F. (Eds.), Deep Drilling Results in the Atlantic Ocean: Continental Margins and Paleoenvironment. Am. Geophys. Union, Maurice Ewing Ser., 3:249-274.

Uyeda, S., and Richards, M. L., 1966. Magnetization of four Pacific seamounts near the Japanese Islands. Tokyo Daigaku Jishin Kenkyusho Iho, 44:179-213.

Date of initial receipt: 27 January 1992

Date of acceptance: 31 March 1992

Ms 129B-144 